\title{
Synaptic Neurotransmitter-Gated Receptors
}

\author{
Trevor G. Smart ${ }^{1}$ and Pierre Paoletti ${ }^{2}$ \\ ${ }^{1}$ Department of Neuroscience, Physiology \& Pharmacology, University College London, \\ London WC1E 6BT, United Kingdom \\ ${ }^{2}$ Institut de Biologie de l'Ecole Normale Supérieure (IBENS), CNRS UMR8197, INSERM U1024, \\ Ecole Normale Supérieure, 75005 Paris, France \\ Correspondence: t.smart@ucl.ac.uk; pierre.paoletti@ens.fr
}

Since the discovery of the major excitatory and inhibitory neurotransmitters and their receptors in the brain, many have deliberated over their likely structures and how these may relate to function. This was initially satisfied by the determination of the first amino acid sequences of the Cys-loop receptors that recognized acetylcholine, serotonin, GABA, and glycine, followed later by similar determinations for the glutamate receptors, comprising non-NMDA and NMDA subtypes. The last decade has seen a rapid advance resulting in the first structures of Cys-loop receptors, related bacterial and molluscan homologs, and glutamate receptors, determined down to atomic resolution. This now provides a basis for determining not just the complete structures of these important receptor classes, but also for understanding how various domains and residues interact during agonist binding, receptor activation, and channel opening, including allosteric modulation. This article reviews our current understanding of these mechanisms for the Cys-loop and glutamate receptor families.

$T^{0}$ understand how neurons communicate with each other requires a fundamental understanding of neurotransmitter receptor structure and function. Neurotransmitter-gated ion channels, also known as ionotropic receptors, are responsible for fast synaptic transmission. They decode chemical signals into electrical responses, thereby transmitting information from one neuron to another. Their suitability for this important task relies on their ability to respond very rapidly to the transient release of neurotransmitter to affect cell excitability.

In the central nervous system (CNS), fast synaptic transmission results in two main effects: neuronal excitation and inhibition. For excitation, the principal neurotransmitter involved is glutamate, which interacts with ionotropic (integral ion channel) and metabotropic (secondmessenger signaling) receptors. The ionotropic glutamate receptors are permeable to cations, which directly cause excitation. Acetylcholine and serotonin can also activate specific cationselective ionotropic receptors to affect neuronal excitation. For controlling cell excitability, inhibition is important, and this is mediated by the neurotransmitters GABA and glycine, causing an increased flux of anions. GABA predominates as the major inhibitory transmitter throughout

Editors: Morgan Sheng, Bernardo Sabatini, and Thomas Südhof

Additional Perspectives on The Synapse available at www.cshperspectives.org

Copyright (C) 2012 Cold Spring Harbor Laboratory Press; all rights reserved; doi: 10.1101/cshperspect.a009662

Cite this article as Cold Spring Harb Perspect Biol 2012;4:a009662 
the CNS, whereas glycine is of greater importance in the spinal cord and brainstem. They both activate specific receptors-for GABA, there are ionotropic and metabotropic receptors, whereas for glycine, only ionotropic receptors are known to date.

Together with acetylcholine- and serotoningated channels, GABA and glycine ionotropic receptors form the superfamily of Cys-loop receptors, which differs in many aspects from the superfamily of ionotropic glutamate receptors. Over the last two decades, our knowledge of the structure and function of ionotropic receptors has grown rapidly. In this article, we summarize our current understanding of the molecular operation of these receptors and how we can now begin to interpret the role of receptor structure in agonist binding, channel activation, and allosteric modulation of Cys-loop and glutamate receptor families. Further details on the regulation and trafficking of neurotransmitter receptors in synaptic structure and plasticity can be found in accompanying articles.

\section{CYS-LOOP RECEPTOR SUPERFAMILY}

In the central and peripheral nervous systems, neurotransmitter-gated ion channels underpin the rapid transfer of information between neurons by permitting the passage of ions across the cell membrane. They are located at presynaptic and postsynaptic sites to affect the excitability of neurons and muscle. Within a few milliseconds following a presynaptic action potential, receptors bind neurotransmitter molecules to initiate channel opening. These channels close just as rapidly after the dissociation of neurotransmitters to terminate synaptic events. The importance of these receptors is exemplified by the diseases that are caused following their dysfunction and by the increasing number of therapeutic agents that target them. Postsynaptic receptors are not confined to synapsestheir extrasynaptic counterparts are responsive to low levels of neurotransmitter mediating a persistent tonic control over cell activity. Thus, their roles are manifold, and with improved structural techniques, it is now possible to assign some function to various domains of Cys- loop receptors, although much remains to be discovered.

\section{Cys-Loop Receptor Gene Families}

The founding members were defined as "Cysloop receptors" because they contain a highly conserved structural signature-a loop formed by a disulfide bridge in the extracellular domain. They are nicotinic acetylcholine receptors (nAChR), type 35 -hydroxytryptamine receptors $\left(5 \mathrm{HT}_{3} \mathrm{R}\right), \gamma$-aminobutyric acid receptors (type $A$ and $C, G A B A_{A} / C R$ ), and glycine receptors (GlyR) (Barnard et al. 1987; Grenningloh et al. 1987; Betz 1990). Also included are the $\mathrm{Zn}^{2+}$ activated cation channel (Davies et al. 2003) and invertebrate receptors activated either by glutamate or serotonin (anionic channels) or GABA (cationic channels) (Ortells and Lunt 1995; Lester et al. 2004), but the related bacterial homologs, Gloeobacter violaceus (GLIC) (Bocquet et al. 2009) and Erwinia chrysanthemi (ELIC) (Hilf and Dutzler 2008), lack the characteristic Cys-loop signature. Consequently, Cys-loop receptors are more precisely referred to as "pentameric ligand-gated ion channels."

Their diversity is extensive, with most subunit families encoded by multiple genes. For the major ligand-gated anion channels, such as $\mathrm{GABA}_{\mathrm{A} / \mathrm{C}} \mathrm{Rs}$, eight subunit families have been identified $(\alpha 1-6, \beta 1-3, \gamma 1-3, \delta, \varepsilon, \pi, \theta$, and $\rho 1-3)$, yielding 19 subunits. Although multiple subunit combinations are possible, prominent among these are $\alpha \beta \gamma$ (stoichiometry 2:2:1) and $\alpha \beta \delta$. In contrast, the $\rho$-subunits preferentially combine together forming either homomeric or heteromeric receptors that are referred to as $\mathrm{GABA}_{C}$ Rs; for GlyRs, two subunit families exist, $\alpha 1-4$ and $\beta$, yielding a total of five subunits. Early on during development, GlyRs form $\alpha$-subunit homomers, later changing to $\alpha \beta$ heteromers (Alexander et al. 2008).

The major ligand-gated cation channels include the extensive nAChR family. Five subunit families are known $(\alpha 1-7,9$ and $10, \beta 1-4, \delta, \varepsilon$, and $\gamma$ ), providing 16 subunits in vertebrates. Subunit combinations at the neuromuscular junction are well known (embryonic: $\alpha_{2} \beta \gamma \delta$; and adult: $\alpha_{2} \beta \varepsilon \delta$ ). For neuronal nAChRs, sub- 
unit assemblies are less clear with $\alpha \beta$ combinations comprising $\alpha(2-6)$ and $\beta(2-4)$. The $\alpha 7$ and $\alpha 9$ subunits can form homomers but also combine with other subunits, such as $\alpha 10(\alpha 9 \alpha 10)$ or $\beta 2\left(\alpha 7 \beta 2\right.$ ). The less-extensive $5-\mathrm{HT}_{3} \mathrm{R}$ family forms cation-permeable channels from only two main subunits, $5-\mathrm{HT}_{3 \mathrm{~A}}$ and $5-\mathrm{HT}_{3 \mathrm{~B}}$. The $5-\mathrm{HT}_{3 \mathrm{~A}}$ subunit either forms homomers or coassembles with $5-\mathrm{HT}_{3 \mathrm{~B}}$. Three other subunits have been reported-5-HT3 $3_{\mathrm{C}-\mathrm{E}}$ - but these primarily affect the expression levels of $5-\mathrm{HT}_{3 \mathrm{~A}}$ and not the receptor's physiological profile (Alexander et al. 2008).

Anchoring Cys-Loop Receptors: Receptor-Associated Molecules and Phosphorylation

The efficacy of synaptic transmission relies heavily on receptor subunit composition and the numbers that cluster opposite axon terminals. Receptor-associated molecules provide a scaffold near the surface membrane that influences receptor trafficking. Moreover, through posttranslational modifications of receptors and/ or scaffolds, receptor expression, function, and plasticity can be regulated (Moss and Smart 2001; Araud et al. 2010; Luscher et al. 2011).

A key component for anchoring $\mathrm{GABA}_{\mathrm{A} / \mathrm{C}}$ Rs and GlyRs at inhibitory synapses is gephyrin, which forms a lattice connecting receptor subunits to the cytoskeleton (Feng et al. 1998; Kneussel and Betz 2000; Sassoe-Pognetto and Fritschy 2000; Luscher and Keller 2004; Jacob et al. 2008; Tyagarajan and Fritschy et al. 2008; Fritschy 2010). There are numerous other proteins, including $\mathrm{GABA}_{\mathrm{A}} \mathrm{R}$-associated protein, Plic-1, Huntingtin-associated protein 1, which affect the surface stability and trafficking of $\mathrm{GABA}_{\mathrm{A}}$ Rs (Luscher and Keller 2004; Luscher et al. 2011). Although not subject to the same research intensity, extrasynaptic receptors can associate with other proteins, for example, $\alpha 5$-subunit-containing $\mathrm{GABA}_{\mathrm{A}} \mathrm{Rs}$ and radixin, which slows diffusion of the receptor in the surface membrane (Loebrich et al. 2006). Anchoring is reversible because neurotransmitter-gated receptors are laterally mobile in the surface membrane, which is a major pathway for replen- ishing receptors at synapses (Thomas et al. 2005; Triller and Choquet 2005; Bogdanov et al. 2006).

Many of these interactions are regulated by phosphorylation of receptor subunits and their associated molecules, affecting receptor trafficking, assembly, and stability in the surface membrane. Consensus sites for serine/threonine and tyrosine kinase phosphorylation of $\mathrm{GABA}_{\mathrm{A} / \mathrm{C}} \mathrm{R}$ and GlyR subunits are located in the intracellular domains between M3 and M4 of $\mathrm{GABA}_{\mathrm{A}} \mathrm{R} \alpha 4, \beta$-, and $\gamma$-subunits, and GlyR $\alpha$-subunits (Moss and Smart 1996). Gephyrin can also be phosphorylated, which is important for inhibitory synaptic plasticity (Tyagarajan and Fritschy 2010).

With regard to clustering $\mathrm{nAChR}$ in skeletal muscle, rapsyn plays a major role with the receptor tyrosine kinase, MuSK, linking via $\beta$ catenin and $\beta$-dystroglycan to form a scaffold between nAChRs and the cytoskeleton (Bruneau et al. 2009). For neuronal nAChRs, although receptor-associated molecules are less well defined, PSD-93, PSD-95, SAP102, and neuregulin-1 affect receptor clustering and surface expression (Neff et al. 2009; Araud et al. 2010; Fernandes et al. 2010). Similar to $\mathrm{GABA}_{\mathrm{A}}$ Rs and GlyRs, nAChRs can also be phosphorylated in their major intracellular domains to affect expression levels and cell surface clustering (Wallace et al. 1991; Charpantier et al. 2005; Lee et al. 2008).

Irrespective of their location, the main function of neurotransmitter-gated ion channels is to rapidly transmit the binding "signal" to the ion channel, opening the gate and permitting ion flux (Lester et al. 2004; Bartos et al. 2009; Cederholm et al. 2009; Chang et al. 2009; Miller and Smart 2010). Our understanding as to how the receptor's underlying molecular machinery is structurally and functionally configured to achieve this rapid response is constantly evolving.

\section{Pentameric Receptor Structure}

Although structure-function studies have been hampered by a lack of crystal structures for Cys-loop receptors, the density of nAChRs in Torpedo marmorata (Unwin 2005) has provided high-resolution images down to $4 \AA$ A. These 
reveal a modular design for $\mathrm{nAChRs} \mathrm{comprising}$ pseudosymmetrical rings of five subunits, each contributing an extracellular domain (ECD) of anti-parallel sets of inner and outer $\beta$-sheets, a four- $\alpha$-helical transmembrane domain (TMD), and an intracellular domain (ICD) of largely unknown structure (Fig. 1). The ECDs are positioned over the TMDs, providing a central aqueous pathway that stretches from the external vestibule formed by the ECDs, on through the TMDs and channel gate, before dissipating via the ICDs (Fig. 1). The signature Cys-loop structure is formed by a disulfide bond and contains 13 amino acids situated at the base of the ECDs. It is an important conduit for communication between the neurotransmitter-binding sites and the ion channel. This overall structure of the receptor agrees reasonably well with the first crystal structure of a Cys-loop receptor, the glutamate-gated $\mathrm{Cl}^{-}$ channel (GluCl) from Caenorhabditis elegans (Fig. 1) (Hibbs and Gouaux 2011). This recep- tor also contains a large ECD, four TMDs, and a Cys-loop, in addition to another Cys bridge in loop C, a feature also present in GlyR $\alpha$-subunits, with which $\mathrm{GluCl}$ shares $43 \%$ primary sequence identity.

\section{The Primary Step: Ligand Binding}

The initial step in the activation pathway involves the binding of a neurotransmitter between neighboring subunit ECDs, coordinated by six binding loops, A-F. Binding loops A-C from one subunit form the principal $(\mathrm{P}$ or + ) face of the binding site, and loops D-F are contributed by the complementary (C or - ) face of the next subunit (Fig. 2) (Corringer et al. 2000). For a homomeric receptor (e.g., GlyR $\alpha 1$ or $\mathrm{GABA}_{\mathrm{C}} \mathrm{R} \rho 1$ ), up to five binding sites are presented, although occupancy of each one is unnecessary for full receptor activation (Amin and Weiss 1996; Beato et al. 2004). For GABA $A_{\text {- }}$ Rs comprising $\alpha 1 \beta 2 \gamma 2$ subunits, two identical

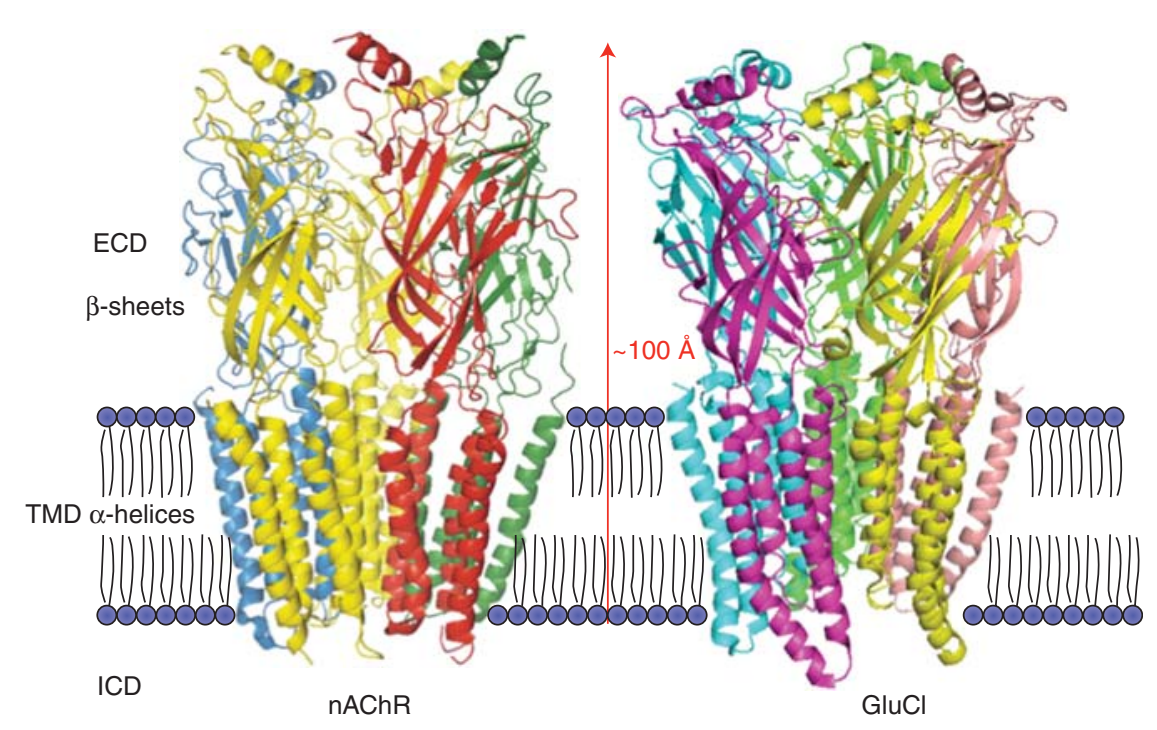

Figure 1. Architecture of Cys-loop receptors. Structure of (left) Torpedo nAChR solved from electron microscopic images at the $4 \AA$ level (pdb 2BG9) (Unwin 2005) and (right) the C. elegans glutamate-gated anion channel at $3.3 \AA$ (pdb 3RIA) (Hibbs and Gouaux 2011). The pentameric subunit assembly and secondary structure are shown for the extracellular domain (ECD) and transmembrane domain (TMD). The ECDs are composed of inner and outer $\beta$-sheets with an $\alpha$-helix, and each subunit's TMD is formed by four $\alpha$-helices (M1-M4). Note that for nAChR, the intracellular (MA) helices preceding M4 are omitted, whereas the M3-MA stretch is disordered and is thus not included in the structure. For the $\mathrm{GluCl}$ structure, the M3-M4 domain is replaced by a tripeptide, A-G-T (Hibbs and Gouaux 2011). 
A

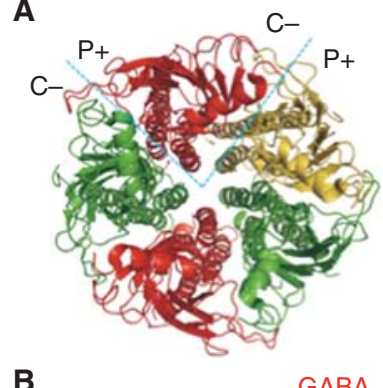

C

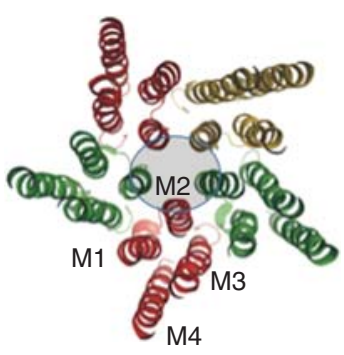

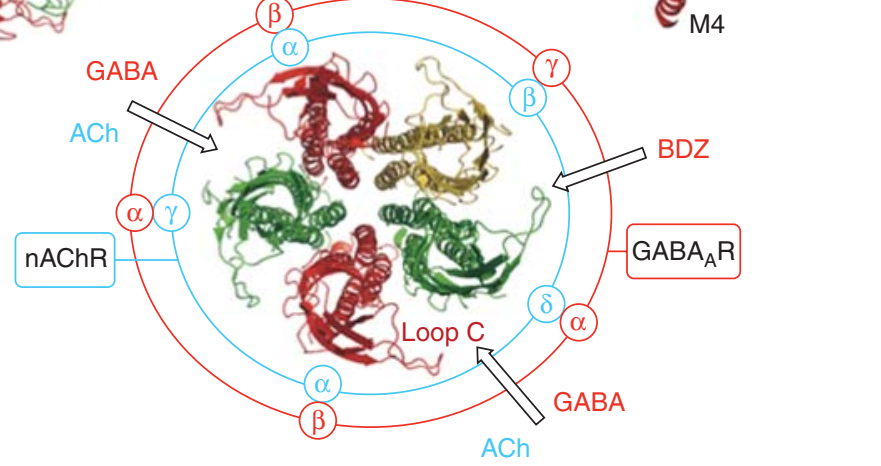

Figure 2. Synaptic view of a Cys-loop receptor. Looking across from the presynaptic terminal over to the postsynaptic membrane, an image of the structure for a typical Cys-loop receptor is shown. This is generated from the atomic resolution structure for AChBP (pdb 2BYQ) (Hansen et al. 2005) for the ECD, linked to the transmembrane domains taken from images of GLIC (Bocquet et al. 2009). (A) The five subunits form a pseudosymmetrical ring with interfacial binding sites between principal $(\mathrm{P},+)$ and complementary $(\mathrm{C},-)$ binding faces. Note the central aqueous pathway for ion conduction. $(B)$ A cut-away slab from $A$ depicts the loop $C$ structures on each subunit and the relative stoichiometry for a muscle $n A C h R$ and neuronal $G A B A_{A} R$. The identity of the subunits and neurotransmitter-binding sites are illustrated. $(C)$ Further cut-away to reveal the tops of the TMDs showing M2 lining the ion channel and the support formed by M1, M3, and M4.

$\beta-\alpha$ interfaces are able to bind neurotransmitter, whereas in muscle nAChRs $(\alpha \beta \gamma \delta)$, these sites are different, being located at $\gamma-\alpha$ and $\delta-$ $\alpha$ interfaces (Karlin and Akabas 1995). Although the agonist binding loops are readily identifiable across the Cys-loop receptor family, the aromatic and hydrophobic residues coordinating agonist binding vary (Ashton and Young 2003; Bohme et al. 2004; Celie et al. 2005a; Hansen et al. 2005; Gay and Yakel 2007; Young et al. 2007).

Understanding how agonist molecules bind has been facilitated by X-ray crystallography of acetylcholine-binding proteins (AChBPs), a group of molluscan proteins (Brejc et al. 2001; Smit et al. 2001; Celie et al. 2005b; Geitmann et al. 2010). Although AChBPs lack TMDs and thus an ion channel, they do assemble into pentamers with a topology resembling the ECDs of nAChRs. As a consequence, they are used exten- sively as templates for structural homology modeling of Cys-loop receptors (Geitmann et al. 2010; Miller and Smart 2010). Such studies reveal that cation $-\pi$ interactions between an agonist's terminal amine and hydrophobic residues in the receptor are critical determinants of binding (Zhong et al. 1998; Beene et al. 2002; $\mathrm{Mu}$ et al. 2003; Celie et al. 2004; Padgett et al. 2007; Pless et al. 2008). Modeling studies will now be considerably enhanced by using the GluCl structure at $3.3 \AA$ resolution (Hibbs and Gouaux 2011).

\section{Agonist Binding Loops A-F}

After agonist binding, structural rearrangements around the binding site are transmitted through the ECD to the TMDs to initiate ion channel opening. Agonist-induced conformational changes to 
loops A, D, and E (Fig. 3) are not readily apparent from AChBP structures, but subtle $(\sim 0.5$ $\AA$ ) movements are detected in residues of loops $\mathrm{C}$ and $\mathrm{D}$ in high-resolution images of $\mathrm{GluCl}$ crystals containing the coagonists glutamate and ivermectin (Hibbs and Gouaux 2011). Mutating specific residues in loops $\mathrm{A}, \mathrm{D}$, and $\mathrm{E}$ causes Cys-loop channels to open spontaneously in the absence of agonist, indicating their importance for receptor activation (Boileau et al. 2002; Torres and Weiss 2002; Sedelnikova et al. 2005; Miller et al. 2008). In particular, loop A and parts of the ECD's hydrophobic core are vital for linking allosteric modulator sites to neurotransmitter binding sites (Miller et al. 2008) and for stabilizing the closed state of the ion channel (Chakrapani et al. 2003; Miller et al. 2008).

For loop $\mathrm{F}$ in $\mathrm{GABA}_{\mathrm{A} / \mathrm{C}} \mathrm{Rs}$, conformational changes do not appear to be associated with receptor activation (Khatri et al. 2009; Wang et al. 2010) with minor movement thought to result from loop F's connection to loop C, possibly signaling the presence of bound ligand (Khatri and Weiss 2010). Nevertheless, movement of loop F during activation of muscle nAChRs has been proposed (Gleitsman et al. 2008).
In comparison with these minimal movements, structural changes can occur in loop B, which sits behind loop $C$ and connects the inner and outer $\beta$-sheets near the top of the ECD. Loop B may interact with loops $\mathrm{A}$ and $\mathrm{C}$ on the principal binding face (Grutter et al. 2003; Lee and Sine 2004; Cashin et al. 2007). After agonist binding, loop B appears to rotate and envelop the agonist molecule in the binding site, and substituting residues in this loop initiates spontaneous channel opening in $\mathrm{GABA}_{\mathrm{A}}$ Rs (Newell et al. 2004).

\section{The Role of Loop C}

The most pronounced movement involves loop C. Cocrystallizing AChBP with an agonist indicates that loop $\mathrm{C}$ moves toward the receptor by $\sim 7 \AA$, "capping" the agonist-binding site (Celie et al. 2004; Hansen et al. 2005). In contrast, antagonist binding to the same site either keeps loop C uncapped or displaces it further away from the receptor (Bourne et al. 2005; Celie et al. 2005a; Hansen et al. 2005). Evidence of loop $\mathrm{C}$ repositioning itself closer to the agonist molecule is also evident in $\mathrm{GluCl}$ (Hibbs and Gouaux 2011). The precise role of capping is

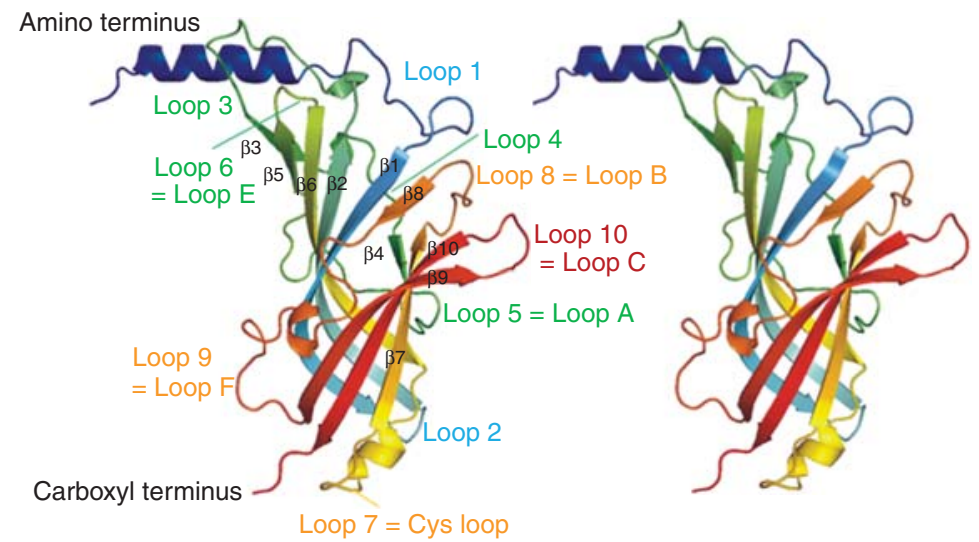

Inner $\beta$ sheet: $\beta 1, \beta 2, \beta 3, \beta 5, \beta 6$, and $\beta 8$ Outer $\beta$ sheet: $\beta 4, \beta 7, \beta 9$, and $\beta 10$

Figure 3. Structure of the extracellular domain. Side view of two adjacent subunits of the AChBP. The positions of the binding loops and other loops from the amino terminus to the carboxyl terminus that adjoins the pre-M1 domain in Cys-loop receptors are shown. $\beta$-strands that form the inner and outer $\beta$-sheets are also indicated with labeling according to Brejc et al. (2001). 
undefined. It could trap agonist molecules at the binding site and/or prime the channel for activation by moving two $\beta$-strands ( $\beta 9$ and $\beta 10$, which support loop C) to initiate movement in the pre-M1 domain. This would transfer the conformational wave from the ECD to the TMD for channel activation (Fig. 3) (Unwin 2005). Loop C capping does occur in spontaneously opening mutant nAChRs in the absence of agonist, suggesting that it is important for channel activation (Mukhtasimova et al. 2009).

A preactivation or "flip" state, which might relate to the loop C capped state, has been proposed from studies of full and partial agonists at nAChRs and GlyRs (Lape et al. 2008). After binding full agonists, the receptor attains the preactivated state far easier than with partial agonists; once preactivated, channel gating proceeds with equal efficiency for either type of agonist. Full agonists are characterized by their higher affinity for preactivated states (Lape et al. 2008). Whether preactivation represents a discrete structural state (e.g., loop C capped state) remains uncertain. If these states are equivalent, then whether an agonist is full or partial will depend on its ability to promote loop C capping. Presently, it is likely that preactivation is one of several structural intermediates that are passed through during the process of receptor activation.

The view that loop C capping is an important early step in preactivation is supported by studies analyzing the effect of mutations on rate equilibrium free-energy relationships. This relies on a simple kinetic scheme and a statistical value $\Phi$, indicating whether a group of residues is similar to an open $(\Phi=1)$ or shut channel state $(\Phi=0)$ (Miller and Smart 2010). Agonist binding induces conformational changes to residues near the binding site early on during activation ( $\Phi$ near to 1) (Grosman et al. 2000). Next the Cys-loop and loop 2 change at near identical times, and finally the M2-M3 linker, which adjoins the ion channel, follows slightly later (lower values of $\Phi$ ) (Purohit and Auerbach 2007). This is plausibly modeled by discrete groups of residues contributing to a conformation wave from the ECD to the TMD. The nearidentical changes that occur after different ago- nists bind to the receptor indicate that the conformational wave is independent of the nature of the agonist (Han et al. 2004). Interestingly, non-binding interfaces also undergo conformational rearrangement when agonist is bound (Wang et al. 2010), which is indicative of a propagated conformational wave.

It is notable that the binding sites for agonists and many allosteric modulators are located at subunit interfaces where movements of the binding loops (Chang and Weiss 2002) and interactions across the interface are important for stabilizing the resting receptor in a shut state (Harvey et al. 1999; Nevin et al. 2003; Miller et al. 2005; Mukhtasimova and Sine 2007; Gleitsman et al. 2008). It is therefore not surprising that destabilizing the interface by mutation can lead to spontaneous channel activation (Miller et al. 2008; Todorovic et al. 2010).

\section{Coupling the Extracellular Domain to the Ion Channel}

Several structures are important for transferring the conformational wave from the ECD to the TMD (Fig. 3), specifically loop 2 ( $\beta 1-\beta 2$, inner $\beta$-sheet), loop 7 (Cys loop, connects inner and outer $\beta$-sheets) and loop 9 (loop F) at the base of the ECD, together with the pre-M1 domain (linked to $\beta 10$ and thus loop C) and the M2-M3 linker (Bouzat et al. 2004).

Loops 2 and 7 arch over the M2-M3 linker, and their displacement after agonist binding may trigger channel opening (Unwin 2005), affecting the accessibility of residues in the M2M3 linker (Bera et al. 2002). An alternative view of channel opening comes from comparing open and shut conformations of GLIC and ELIC. This suggests that loop 2 moves down toward the ion channel (Bocquet et al. 2009), outwardly displacing the Cys-loop and the M2-M3 linker. This allows the M2 helices to retract toward M1, M3, and M4, opening the channel (Fig. 2).

Loop 9 and the pre-M1 domain in the ECD could also interact with the TMD (Lyford et al. 2003; Newell and Czajkowski 2003; Bouzat et al. 2004). Although the pre-M1 domain is structurally rigid during receptor activation (Unwin 2005; Hilf and Dutzler 2008, 2009; Bocquet 
et al. 2009), it may interact with the Cys-loop and the M2-M3 linker to link agonist binding to channel activation (Castaldo et al. 2004; Lee and Sine 2005; Mercado and Czajkowski 2006; Lee et al. 2009) acting as a pivot around which other domains move (Hu et al. 2003; Lee and Sine 2005).

The nature of the contacts between the ECD and TMD relies on hydrophobic and electrostatic interactions (Absalom et al. 2003; Kash et al. 2003; Lee and Sine 2005; Unwin 2005; Xiu et al. 2005; Price et al. 2007). The hydrophobic contacts are well conserved across the Cys-loop family, whereas the electrostatic interactions vary. Overall, the electrostatic environment is more important than the location of individual charged residues (Absalom et al. 2003; Kash et al. 2003; Xiu et al. 2005).

The critical importance of the M2-M3 linker for Cys-loop receptor activation is shown by the dysfunction that is caused by naturally occurring pathogenic mutations within this domain, which include congenital myasthenic syndrome $(n A C h R)$, epilepsy $\left(G_{A B A} R\right)$, and hyperekplexia (GlyR) (Breitinger and Becker 2002; Engel et al. 2003; MacDonald et al. 2004; Chung et al. 2010).

\section{Ion Channel Domain}

Electron microscopy of nAChR channels shows that each subunit contributes its M2 domain to a ring of five $\alpha$-helices (Miyazawa et al. 2003). A tapering of the helices causes the ion channel pore to widen at the extracellular end with a "kink" in the middle of each $\alpha$-helix (Fig. 4). The ion channel is stabilized by contacts between neighboring M2 helices and by the M1 and M3 helices behind forming a supporting ring for the channel (Miyazawa et al. 2003).

Structurally, the pore lining of the channel is highly conserved and composed of concentric rings of similar residues. Some of these rings are hydrophobic ( $9^{\prime}$-leucine and $16^{\prime}$-leucine in nAChRs). Highly conserved, positively charged residues at the cytoplasmic end of M2 are defined as $0^{\prime}$, increasing to another ring of negatively charged residues at the extracellular end defined as $20^{\prime}$. Others are polar $\left(2^{\prime}\right.$-threonine,
6 -serine). At both ends of $\mathrm{M} 2$, rings of residues with charged side chains can be found $\left(-1^{\prime}\right.$ glutamate, $20^{\prime}$-glutamate for nAChRs). These homologous rings are also broadly conserved in ELIC, GLIC (Bocquet et al. 2009), and GluCl (Fig. 4) (Hibbs and Gouaux 2011).

\section{Opening the Ion Channel}

How the ion channel opens is still not completely understood. For nAChRs, a rotation of M2 $\alpha$-helices to remove the kinked region from the conduction pathway has been proposed (Unwin 2005). It is around the M2 kink that the $\alpha$-helices converge to form the principal channel gate with hydrophobic rings $\left(9^{\prime}\right.$ leucines and $13^{\prime}$-valines), constricting the channel to $\sim 6 \AA$ in diameter (White and Cohen 1992; Banks et al. 2000; Miyazawa et al. 2003; Arevalo et al. 2005; Unwin 2005). The two $\alpha$-subunit M2 helices are the first to move during receptor activation (Purohit et al. 2007), presumably destabilizing the channel gate to allow other $\alpha$-helices to retract and complete channel opening. When the channel opens, the pore diameter increases following retraction of M2 toward M1 and M3 (Miyazawa et al. 2003; Unwin 2005), which is permitted by an aqueous cavity (Wick et al. 1998; Bera et al. 2002; Bera and Akabas 2005; Brannigan et al. 2008). An outward tilting motion in M2 could also explain channel opening (Cymes et al. 2005; Paas et al. 2005) following a comparison of ELIC and GLIC channels. This involves an outward movement of the M2-M3 linker, pulling and tilting M2 to open the channel (Fig. 4) (Hilf and Dutzler 2008; Bocquet et al. 2009).

\section{Ion Selectivity Filter}

At either end of the ion channel, there are charged rings of residues that regulate channel conductance (Fig. 4) (Imoto et al. 1988; Langosch et al. 1994; Wang et al. 1999; Moorhouse et al. 2002). For nAChRs and $5 \mathrm{HT}_{3} \mathrm{Rs}$, the rings are negatively charged, selecting for cations, whereas for $\mathrm{GABA}_{\mathrm{A} / \mathrm{C}} \mathrm{Rs}$ and GlyRs, the rings are net positive and thus anion selective (Keramidas et al. 2004). 


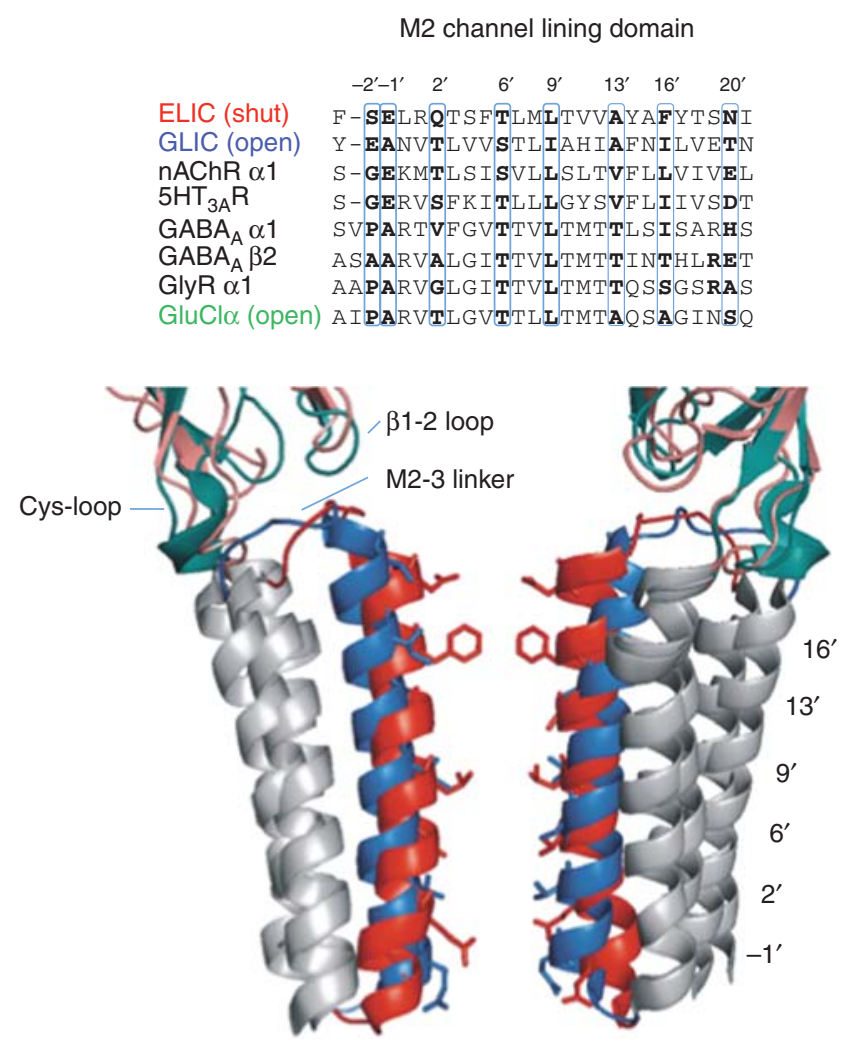

Figure 4. Cys-loop receptor ion channel domain. The M2 domains of several Cys-loop receptors are aligned; those residues that are exposed and lining the channel lumen are boxed. The structural model shows the M2 domains of open GLIC and closed ELIC. For GLIC, the $\beta 1-2$ loop (green) moves downward and outwardly displaces the M2-M3 linker (blue) hauling the M2 domains (blue) upward and tilting outward to open the channel compared with ELIC ( pink and red).

Reducing charge density at the extracellular $20^{\prime}$-ring promotes outward rectification (Imoto et al. 1988; Moorhouse et al. 2002), in accord with an effect on the concentration of permeant ions in the channel vestibule (Keramidas et al. 2004). In comparison, mutating the cytoplasmic ring $\left(-1^{\prime}\right)$ symmetrically affected membrane current. This ring is located at the narrowest point of the open channel and contributes to the main ion selectivity filter. Indeed, substituting residues in $\mathrm{nAChR} \alpha 7$ and $5 \mathrm{HT}_{3}$ Rs to replicate those in GlyRs switched the ionic permeability from cationic to anionic (Galzi et al. 1992; Corringer et al. 1999; Gunthorpe and Lummis 2001). Switching GlyR and $\mathrm{GABA}_{C} \mathrm{R}$ permeability from anionic to cationic can be achieved by the reverse substitutions (Kerami- das et al. 2000, 2002; Miller and Smart 2010). Analysis of anion binding in $\mathrm{GluCl}$ crystals suggests that the $-2^{\prime}$-proline forms part of an electropositive ion binding "pocket," increasing bulk ion concentration at the cytoplasmic end of the channel. As such, the $-2^{\prime}$-position is thought to be part of the pore lining for anionand cation-selective Cys-loop receptors (Fig. 4) (Hibbs and Gouaux 2011). Interestingly, for heteromeric $\alpha \beta \gamma \mathrm{GABA}_{\mathrm{A}} \mathrm{Rs}$, switching ion permeability only requires substitution of residues in the $\beta 3$ subunit (Jensen et al. 2002), indicating its greater contribution toward ion selection.

Outside the ion channel, there are key residues that have a significant impact on channel conductance. For $5-\mathrm{HT}_{3 \mathrm{~A}} \mathrm{Rs}$, by replacing a group of arginine residues in the M3-M4 
intracellular domain with alanines or by coexpressing with the $5-\mathrm{HT}_{3 \mathrm{~B}}$ subunit, single-channel conductance was markedly increased ( $\mathrm{Da}$ vies et al. 1999; Kelley et al. 2003). Positively charged arginines were thought to line the portals formed by the internal subunit interfaces (Miyazawa et al. 2003; Unwin 2005) hampering cation flux by electrostatic interaction (Miyazawa et al. 2003; Peters et al. 2005; Unwin 2005).

With respect to the extracellular domain, ions entering the channel must first pass through an outer vestibule formed from the ECDs of each subunit. This vestibule narrows to $\sim 20 \AA$ in diameter (Brejc et al. 2001; Unwin 2005) and contains either a ring of negatively charged residues in nAChRs or positively charged residues in anion-selective channels (Hansen et al. 2008). Increasing positive charge density in the vestibule lowered the nAChR channel conductance (Hansen et al. 2008). These rings of residues may be important for bulk concentration of permeant ions in the vestibule just outside the ion channel; equally plausible is a role as an outer selectivity filter along the ion permeation pathway.

Our understanding of the main components involved in Cys-loop receptor activation continues to evolve. Nevertheless, we need greater clarity regarding the role of agonist-binding loops and interactions across the subunit interfaces during receptor activation, and how the conformational wave spreads toward the key interface between the ECD and the TMD. We are less clear about the mechanisms involved in channel opening - exactly what role does loop C capping actually play? No doubt the structures for AChBP, GluCl, GLIC, and ELIC, in tandem with the high-resolution images of nAChRs, will provide insight.

Finally, one area that has lagged significantly behind concerns the structural determination of a Cys-loop receptor's large intracellular domain and how it is modified in response to signaling and other receptor-associated molecules and scaffold proteins. An understanding of the fundamental processes is important for establishing how drugs modulate the activities of Cys-loop receptors and, importantly, how dysfunction to their signaling is a pivotal cause of debilitating disease.

\section{IONOTROPIC GLUTAMATE RECEPTORS}

The vast majority of excitation in the central nervous system is mediated by glutamate, a ubiquitous amino acid (Watkins and Jane 2006). In neurons, glutamate is packed within synaptic vesicles by dedicated vesicular transporters (the vGluTs) and following presynaptic activity is released in the synaptic cleft. It then diffuses rapidly across the synaptic cleft and activates ionotropic glutamate receptors (iGluRs) localized primarily on the postsynaptic membrane. Because iGluRs form ion channels that flux cations, and not anions, activation of iGluRs results in membrane depolarization. Besides mediating the basic excitatory synaptic responses, iGluRs are also central in the induction and maintenance of synaptic plasticity, long-term changes in synaptic efficacy that underlie the remarkable capacity of the brain to store and retrieve information over extended periods of time.

\section{Multigenic Families and Subunit Composition Diversity}

Mammalian iGluRs are encoded by a total of 18 genes that assemble into four major families: the AMPA, kainate, NMDA, and delta receptors (AMPARs, kainateRs, NMDARs, and deltaRs, respectively) (Fig. 5) (Hollmann et al. 1989; Seeburg 1993; Nakanishi and Masu 1994; Dingledine et al. 1999). The excitatory postsynaptic current is typically mediated by members of the AMPA and NMDA families. KainateRs are found both on presynaptic and postsynaptic compartments and have a role more modulatory than direct at synapses (Lerma 2006; Contractor et al. 2011). DeltaRs are the least understood iGluRs largely because, in contrast to other iGluRs, their apparent incapacity to gate an ion channel following ligand binding makes them electrically "silent" (Kohda et al. 2000; Schmid et al. 2009). There are four AMPAR genes (GluA1-4, also known as GluR1-4); five kainateR genes (GluK1-5, also known as GluR5-7, KA12); seven NMDAR genes (GluN1;GluN2A-D; GluN3A-B, also known as NR1; NR2A-D; NR3A-B), and two $\delta$-subunits (GluD1-2, also known as $\delta 1$ and $\delta 2$ ). 


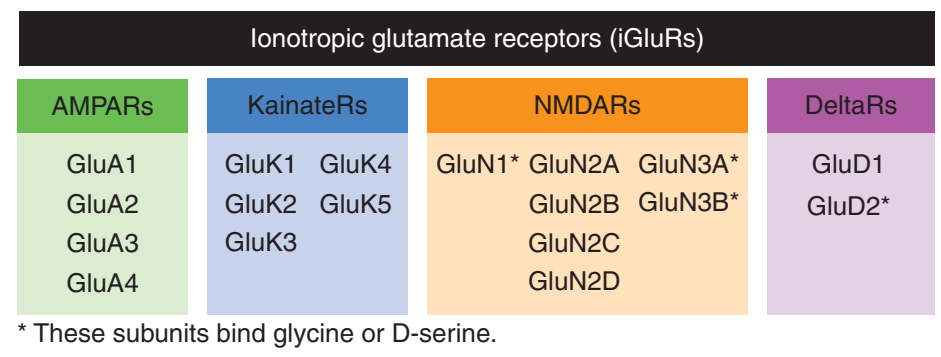

Figure 5. The four families of iGluR subunits. Each subunit is encoded by a distinct gene. There is no known mixing of subunits between families.

Functional iGluRs are formed exclusively by subunits within the same family. AMPAR subunits can form both homo- and heteromers, most native AMPARs being of the latter type (Jonas and Burnashev 1995; Rossmann et al 2011). In kainateR, only GluK1-GluK3 subunits can function as homomers; GluK4 and GluK5 form functional receptors only when coexpressed with GluK1-GluK3 (Contractor et al. 2011). NMDARs are obligatory heteromers associating two GluN1 subunits with either two GluN2 subunits (which can be of different type) or a combination of GluN2 and GluN3 subunits (Cull-Candy and Leszkiewicz 2004; Ulbrich and Isacoff 2007; Paoletti 2011). Functional GluN1/GluN3 complexes, activated by glycine but not glutamate, have also been described in heterologous systems but not in native situations (except on myelin) (Henson et al. 2010; Piña-Crespo et al. 2010). Finally, the $\delta$-subunits mainly form homomeric receptors. Overall, it appears that within each family (the deltaR excepted), differential coassembly of subunits generates a large number of receptor subtypes. This diversity is further enhanced by posttranscriptional modifications of several iGluR genes. The GluN1 subunit, all four AMPAR subunits, and kainateR subunits GluK1GluK3 are subjected to alternative splicing (Monyer et al. 1991; Dingledine et al. 1999). AMPA and kainate receptor genes can also undergo RNA editing, which leads to single-amino-acid exchanges with important functional consequences (Seeburg and Hartner 2003). The iGluR subunits also experience posttranslational modifications including phosphorylation (see below), palmitoylation, and SUMOylation (Traynelis et al. 2010).

The iGluRs are thus diverse in their subunit composition, and each receptor subtype displays unique functional properties. In vivo, the extent of iGluR diversity ultimately depends on which genes are expressed in a given neuron. In the hippocampus, for instance, interneurons and principal cells express different iGluR subunits (Isaac et al. 2007). Even within an individual neuron, iGluR subtypes can differ from one synapse to another, in an input-specific manner, highlighting the critical importance of subunit composition in defining the receptor signaling properties (Köhr 2006). The synaptic content in iGluR subtypes varies according to developmental stages, activity, and disease. During certain forms of synaptic plasticity, subunits can rapidly (within minutes) be replaced one for another, thus affecting the synaptic phenotype (Liu and Cull-Candy 2000; Bellone and Nicoll 2007; Mameli et al. 2007).

\section{Interactions with Intracellular Proteins}

Similarly to Cys-loop receptors, iGluRs are the targets of a variety of intracellular kinases. Serine/threonine phosphorylation by cAMP-dependent protein kinase A (PKA), protein kinase $\mathrm{C}$ (PKC), and calcium/calmodulin-dependent protein kinase II (CAMKII), as well as tyrosine phosphorylation by Src and Fyn kinases have been described. Phosphorylation sites are usually found in the carboxy-terminal tails and regulate receptor trafficking, localization, binding to other intracellular proteins, and, in 
some cases, channel activity (Salter and Kalia 2004; Chen and Roche 2007; Shepherd and Huganir 2007; Traynelis et al. 2010).

The intracellular tails of iGluR subunits, which in the case of GluN2 NMDAR subunits are particularly long ( $>400$ residues), are also the locus for direct interactions with numerous intracellular proteins other than kinases. Many of these proteins are scaffolding or cytoskeletal proteins that are core components of the postsynaptic density (PSD). This is the case of the actin-binding proteins $\alpha$-actinin and spectrin and of several members of the large family of modular PDZ-containing proteins (also known as membrane-associated guanylate kinases, or MAGUKs), including GRIP and PICK1 for AMPARs and PSD-95, SAP102, SAP97, and PSD93 (also known as chapsyn-110) for NMDARs (Wenthold et al. 2003; Kim and Sheng 2004; Montgomery et al. 2004; Shepherd and Huganir 2007). By controlling the transport and clustering of glutamate receptors as well as the recruitment of multiple signaling proteins, MAGUKs play key roles in the structural and functional changes that excitatory synapses experience during development, plasticity, and disease (Lau and Zukin 2007; Sheng and Hoogenraad 2007; Gardoni et al. 2009).

\section{Modular Architecture}

Unlike Cys-loop receptors, which assemble as pentamers, iGluRs form tetramers (Rosenmund et al. 1998; Sobolevsky et al. 2009). Each iGluR subunit has a characteristic modular organization consisting of four discrete domains (Wo and Oswald 1995; Mayer 2006; Traynelis et al. 2010): (1) a large extracellular aminoterminal domain (ATD or NTD; 380 amino acids) that participates in subunit-specific receptor assembly and modulation; (2) an agonist-binding domain $(\mathrm{ABD}$, also known as the S1S2 domain; 300 amino acids), binding glutamate or glycine (or D-serine) in GluN1, GluN3, and GluD2 subunits; (3) a transmembrane domain (TMD) composed of three membrane-spanning segments (M1, M3, and M4) plus a short reentrant loop (M2) and that forms the ion channel; and (4) a cytoplasmic carboxy- terminal domain (CTD), highly variable in length and involved in receptor trafficking, subcellular localization, and coupling to intracellular signaling complexes.

The typical kit design of iGluRs likely arose during evolution through the fusion of separate genes that in bacteria encode individual proteins (Mayer 2006). Thus, whereas the TMD has sequence homology with bacterial potassium channels, the NTD and ABD are each related to clamshell-shaped bacterial periplasmicbinding proteins. Domains behave in a semiautonomous fashion. They can be transplanted between subunits or expressed in isolation while retaining functionality (such as ligand binding). Interestingly, prokaryotes appear to express "simplified" versions of iGluRs, lacking both the NTDs and CTDs but with a functional gating core machinery (ABDs + TMD) (Chen et al. 1999; Janovjak et al. 2011).

The first views of a full-length iGluR were obtained using electron microscopy (EM) imaging of single particles from recombinant and native AMPARs (Tichelaar et al. 2004; Nakagawa et al. 2005). Despite their low resolution $(\sim 30 \AA)$, EM images revealed interesting features such as twofold, rather than fourfold, rotational symmetry, and in the membrane region, electron dense material tightly associated with the TMD and assigned to auxiliary subunits (see below). A major breakthrough in the field was achieved with the crystal structure of a fulllength AMPAR (rat GluA2 homotetramer), thus providing the first atomic map of an iGluR (Fig. 6) (Sobolevsky et al. 2009). The structure revealed a massive Y-shaped complex in which the three major domains are arranged in layers: at the "bottom," the TMD that forms the ion channel; at the "top," the NTD layer with the four individual NTDs; and sandwiched in between these two layers, the ABDs. There are surprisingly few contacts between the various layers. Connections between layers are made by short $(<20$ amino acids) polypeptide stretches, or linkers, that adopt an extended conformation. In agreement with their location, these linkers play critical roles in transducing conformational changes in the extracellular domains into modifications of channel activity (Yelshansky et al. 


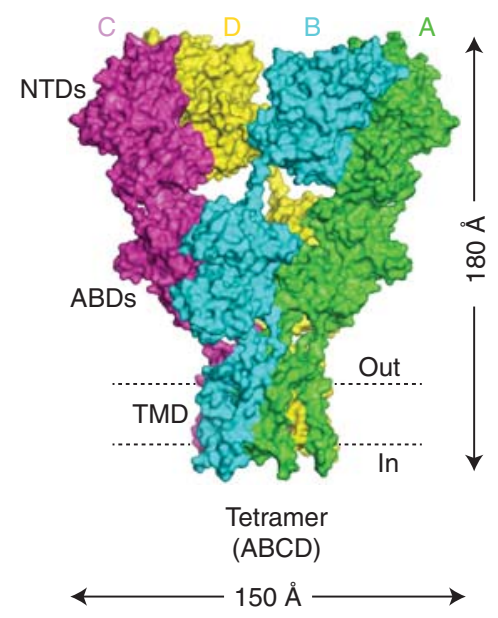

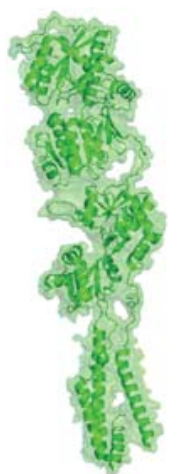

Subunit A (identical to C)

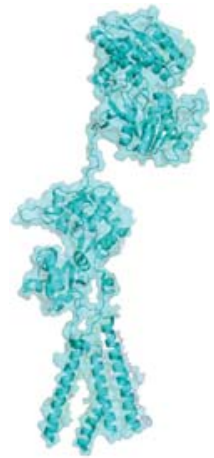

Subunit B (identical to D)

Figure 6. The tetrameric structure of the AMPA GluA2 receptor. (Left) X-ray crystal structure of the AMPA GluA2 homotetrameric receptor (Sobolevsky et al. 2009). Each subunit is in a different color. The tetramer shows a typical layer organization with at the "top" the amino-terminal domains (ATDs or NTDs), at the "bottom" the transmembrane domain (TMD) where the ion channel sits, and sandwiched between the two the agonist-binding domains (ABDs or S1S2 domains) binding glutamate (or glycine/D-serine). (Right) Subunit non-equivalence. $\alpha$-Carbon traces of subunit A and subunit B with the ABDs similarly oriented. Note the striking difference in overall domain orientation between the two subunits.

2004; Schmid et al. 2007; Gielen et al. 2009; Talukder et al. 2010). In the NTD layer, the NTDs arrange as two dimers. Similarly, each ABD partners with the neighboring $\mathrm{ABD}$, forming two pairs of local dimers. Contrasting with this twofold symmetrical dimer-of-dimers organization, the pore region exhibits the typical fourfold symmetry seen in potassium channels. Accompanying this symmetry mismatch, another key feature revealed by the GluA2 structure is "domain swapping." Thus, if at the NTD level, subunit A pairs with subunit $B$ (A/B dimer) and subunit $\mathrm{C}$ with subunit $\mathrm{D}$ (C/D dimer), at the $\mathrm{ABD}$ level, the two pairs engage different subunits (A/D and $\mathrm{B} / \mathrm{C}$ dimers). Crossover of subunit pairing likely helps to stabilize the large and loosely packed extracellular region. As a consequence of symmetry mismatch and domain swapping, the GluA2 receptor presents two pairs of conformationally distinct subunits (despite identical sequences). This nonequivalence in subunit structure is without precedent for an ionotropic receptor. It suggests differential effects on the gating machinery depending on which pair of subunits is considered. The significance of domain swapping and structural non-equivalence is likely to be of paramount importance in the function of iGluRs composed of distinct subunits (heteromers), which in native tissues are the majority.

\section{The Ion Channel and Permeation Properties}

Resembling an inverted potassium channel, the pore of iGluRs has a cone shape structure, with a cytoplasmic base and an extracellular apex (Sobolevsky et al. 2009). The ion conduction pathway resembles an hourglass, with a region of narrow constriction separating two cavities. The M2 segment (or P-loop) lines the inner cavity, whereas the four M3 helices form the wall of the central cavity. Ion replacement experiments have estimated the dimension of the narrow constriction to be $\sim 0.55-0.75 \mathrm{~nm}$ in diameter (Villarroel et al. 1995; Zarei and Dani 1995; Burnashev et al. 1996). The M1 and M4 helices reside on the exterior of the ion channel domain. In the GluA2 structure, the M4 segments have a striking location, with each M4 helix resting on the ion channel core (M1-M3) of the neighboring subunit. The extensive subunit-subunit 
interactions mediated by the M4s likely contribute to the stabilization of the tetrameric assembly.

Although Cys-loop receptors can either flow cations or anions, iGluRs display strong cation selectivity. The flush of $\mathrm{Na}^{+}$ion entry following synaptic iGluR activation is what depolarizes the neuronal membrane. The mechanisms that exclude anions from permeating are ill defined but likely involve both steric and electrostatic effects (Kuner et al. 2001). The various iGluR subtypes differ in their unitary conductance, selectivity for divalent cations, and channel block (Traynelis et al. 2010).

Two key permeation properties that have major impact on synaptic function are the high calcium permeability and magnesium block of NMDAR channels. Extracellular $\mathrm{Mg}^{2+}$ ions inhibit NMDARs by "plugging" the receptor ion channel (Mayer et al. 1984; Nowak et al. 1984). The strong voltage dependence of $\mathrm{Mg}^{2+}$ block endows NMDARs with a unique capacity of coincidence detection between presynaptic and postsynaptic activities, which is central to associative learning (Bliss and Collingridge 1993). The high calcium permeability is another prominent feature of NMDARs that is essential for synaptic plasticity by triggering intracellular cascade activation (Lau and Zukin 2007; Bingol and Sheng 2011). The calcium permeability of NMDAR channels is higher than that of any other ligand-gated ion channel (Rogers and Dani 1995). Thus, at typical GluN1/GuN2A or GluN1/GluN2B receptors, $>15 \%$ of the total inward current is carried by $\mathrm{Ca}^{2+}$ ions (vs. $\sim 4 \%$ for the most $\mathrm{Ca}^{2+}$-permeable AMPARs) (Burnashev et al. 1995; Schneggenburger 1996). The detailed molecular mechanisms that allow $\mathrm{Ca}^{2+}$ ions, but not the smaller $\mathrm{Mg}^{2+}$ ions, to permeate NMDAR channels are still enigmatic.

A key determinant of $\mathrm{Ca}^{2+}$ permeation and $\mathrm{Mg}^{2+}$ block in NMDARs, but also of the permeation properties of all iGluRs, is the residue occupying the tip of the M2 loop. This site, coined the "QRN site," is located halfway in the membrane and forms the region of narrowest constriction in the pore. It harbors either a glutamine $(\mathrm{Q})$ or arginine (R) in AMPA and kainate receptors and an asparagine $(\mathrm{N})$ in (GluN3-lacking) NMDARs (Hume et al. 1991;
Verdoorn et al. 1991; Burnashev et al. 1992; Mori et al. 1992; Sakurada et al. 1993). Not surprisingly given its strategic position in the ion conduction pathway, the QRN site influences every aspect of iGluR permeation properties (Traynelis et al. 2010). It is also a site subjected to RNA editing. In the primary transcripts of GluA2, GluK1, and GluK2, the codon encoding a glutamine can be edited to an arginine (Sommer et al. 1991; Seeburg and Hartner 2003). The presence of the positively charged arginine in edited versions of AMPA and kainate receptors causes low single-channel conductance and strongly reduces calcium permeability and block by intracellular polyamines (Traynelis et al. 2010). In the adult brain, the GluA2 subunit is widespread and exists almost exclusively in its edited version $\left(\mathrm{Ca}^{2+}\right.$ impermeable). During development, however, many neurons express low levels of GluA2 subunits rendering AMPARs $\mathrm{Ca}^{2+}$ permeable, a property exploited for synapse maturation (see Traynelis et al. 2010). The paramount importance of the $Q R N$ site in iGluR function is to be found in the clinic: A defect in GluA2 RNA QRN site editing has been detected in spinal motor neurons of certain patients with amyotrophic lateral sclerosis (Kawahara et al. 2004), and a single substitution (N to K [lysine]) at the QRN site of the GluN2A NMDAR subunit causes severe mental retardation in children (Endele et al. 2010).

\section{Agonist Recognition}

The agonist-binding domains (ABDs) are the best characterized parts of iGluRs. Numerous high-resolution crystal structures of ABDs in complex with a wide variety of ligands, including agonists and antagonists, have been solved (Armstrong et al. 1998; Armstrong and Gouaux 2000; Mayer 2006; Pohlsgaard et al. 2011). All ABDs display a common clamshell-like fold made of two lobes separated by a large central cleft. Unlike the Cys-loop receptors, where agonist binds at an interface between subunits, in GluRs, each subunit carries its own agonistbinding site. Thus, a typical AMPA or kainate receptor exhibits four distinct glutamate-binding sites, whereas "classical" (GluN3-lacking) 
NMDARs harbor two glutamate-binding sites (on GluN2 subunits) and two glycine (or D-serine)-binding sites (on GluN1 subunits) (Furukawa et al. 2005). Agonists are nestled within the interlobe cleft, interacting with both lobes (Mayer 2006). Lobe 1 residues interact with the $\alpha$-amino and $\alpha$-carboxy groups of the agonist molecule and are highly conserved among the four iGluR families. Subunit selectivity arises mostly from amino acid differences in lobe 2 and steric occlusion effects (Mayer 2005, 2006; Pohlsgaard et al. 2011). Another striking feature is the small size of the agonistbinding pockets of GluN1 and GluN3 subunits, which bind glycine or D-serine but not glutamate. The replacement of a tyrosine by either a methionine in GluN3A and GluN3B or a tryptophan in GluN1 greatly reduces the interlobe cavity size, thus preventing glutamate binding (Furukawa et al. 2003; Yao et al. 2008).

\section{Channel Activation, Partial Agonism, and Antagonism}

A fundamental aspect of ionotropic receptors is their ability to rapidly convert (millisecond time scale) chemical energy, that is, agonist-binding interactions, into mechanical work allowing channel gate opening. The basic principles of channel activation are shared by all iGluR subtypes and involve the following events (Fig. 7) (Madden 2002; Mayer 2006; Hansen et al. 2007): (1) Agonists bind the ABD central cleft and promote its closure. (2) Because the ABDs pack as pairs through apposition of their upper lobes whereas the lower lobes are more flexible, $A B D$ closure increases the distance between $\mathrm{ABD}$ lower lobes. (3) This movement, in turn, produces tension on the ABD-TMD linkers, eventually leading to channel gate opening. In this process, subunit dimerization is essential because it allows agonist-triggered cleft closure in an ABD dimer to be transduced into separation of the ABD lower lobes. This separation is the mechanical force that drives the channel open.

Crystal structures of iGluR ligand-binding cores in complex with different ligands offer a straightforward explanation for partial agonism and competitive antagonism. Competitive an- tagonists, such as NBQX at AMPARs or DCKA at NMDARs, prevent channel activation simply because they lock the ABD in an open-cleft conformation by a foot-in-the-door mechanism (Armstrong and Gouaux 2000; Furukawa et al. 2003; Mayer 2006). Partial agonists, on the other hand, display a submaximal efficacy because they induce less domain closure than full agonists, thus reducing the coupling efficiency to channel opening (Armstrong and Gouaux 2000; Jin et al. 2003). At AMPA and kainate receptors, there is thus a correlation between the degree of cleft closure and the level of receptor activation (Mayer and Armstrong 2004). Although appealing, this mechanism seems not to apply to NMDARs. At these receptors, partial agonists induce similar extent of $\mathrm{ABD}$ closure as full agonists (Inanobe et al. 2005; Yao et al. 2008). What would differ then is the stability of the closed-cleft conformation, with partial agonists inducing lower stability (certain agonists may behave likewise at AMPARs) (Birdsey-Benson et al. 2010). Another important variation between NMDARs and non-NMDA (AMPA and kainate) receptors is the stoichiometry of activation. Although a non-NMDAR can open (although submaximally) with a mixture of empty and ligandbound ABDs (Clements et al. 1998; Rosenmund et al. 1998; Smith and Howe 2000), activation of an NMDAR requires obligate occupancy of its four agonist-binding sites (2 glutamate +2 glycine/D-serine molecules) (Benveniste and Mayer 1991; Clements and Westbrook 1991; Schorge and Colquhoun 2005).

The channel gate, the structure that occludes ion passage in the closed state and that dilates following receptor activation, resides at the extracellular entrance of the pore. It is formed by the second half of the transmembrane M3 segment, a region that contains the most highly conserved motif (SYTANLAAF) among all iGluR subunits (Wollmuth and Sobolevsky 2004; Chang and Kuo 2008). In the GluA2 structure (captured in a closed state) (Sobolevsky et al. 2009), the four M3 helices cross at the level of this conserved motif, thus forming a tight steric closure of the ion conduction pathway. Upon receptor activation, the 
T.G. Smart and P. Paoletti

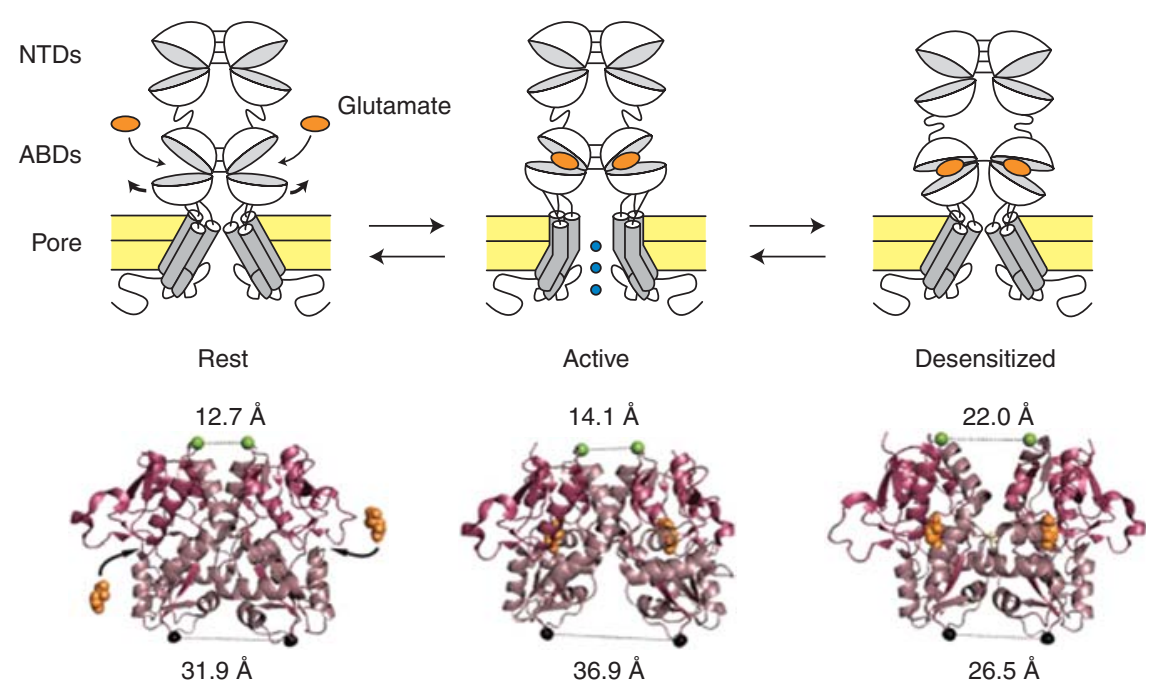

Figure 7. Structural mechanism of iGluR activation and desensitization. A single dimer is represented; a full receptor is a tetramer made of two such dimers. (Below) The crystal structures of the GluA2 ABD dimer in conformations that correspond to the resting state (no ligand bound; pdb code 1FT0), the active state (glutamatebound; pdb code 1FTJ), and the desensitized state ( $\mathrm{pdb}$ code 2I3V). The distances between the two protomers, at the top of the upper lobes (green spheres; dimer interface) and at the bottom of the lower lobes (black spheres; connections to the transmembrane segments), are indicated (Armstrong et al. 2006).

swinging of the ABD lower lobes (see above) is thought to splay apart the M3 bundle through rotating movements of the individual M3 helices. In the Lurcher mutant mice, neurodegeneration occurs because of a point mutation in the SYTANLAAF motif of the GluD2 subunit producing constitutively active (open) channels (Zuo et al. 1997).

\section{Receptor Desensitization}

A hallmark of ionotropic receptors is desensitization, a process by which an activated receptor enters an inactivated state with its ion channel closed even though the neurotransmitter is still bound to the receptor (Jones and Westbrook 1996). Receptor desensitization limits ion flow following agonist binding. The extent and kinetics of desensitization vary widely between iGluR subfamilies. It is particularly fast and pronounced at AMPA and kainate receptors, occurring within a few milliseconds and producing $>90 \%$ decrease in current amplitude at steady state (see Fig. 8B). Desensitization of AMPARs affects how these receptors encode information, because the degree of receptor desensitization can influence the shape of the postsynaptic response (Jones and Westbrook 1996). The critical in vivo importance of AMPAR desensitization was recently revealed by the dramatic phenotype-early postnatal lethality_of mice harboring a single-point mutation eliminating GluA2 AMPAR desensitization (Christie et al. 2010).

At the molecular level, desensitization of AMPA and kainate receptors results from the disruption of the ABD dimer assembly. The repositioning of the $\mathrm{ABD}$ lower lobes closer one to another relaxes the tension exerted on the ABD-TMD linkers, thus allowing channel gate closure (Fig. 7) (Sun et al. 2002; Armstrong et al. 2006; Mayer 2006; Hansen et al. 2007). The stability of the ABD dimer interface is the key parameter that governs the transition to the desensitized state. Accordingly, factors that affect ABD dimerization affinity, such as subunit composition, alternative splicing, or RNA editing, influence desensitization properties (Stern-Bach et al. 1998; Traynelis et al. 2010). 


\section{Allosteric Modulation}

The iGluRs, like many other membrane signaling receptors, possess binding sites distinct from the ion channel and agonist-binding sites that allow for modulation of receptor activity. These allosteric sites usually recognize ions or small molecule ligands that can either be endogenously present in the CNS, or exogenous acting like drug compounds. There is currently great interest in exploiting the allosteric potential of iGluRs for pharmacological and therapeutic purposes (Mony et al. 2009; Traynelis et al. 2010). Notably, allosteric modulation offers the possibility of targeting a specific subunit, and thus a single receptor subtype, something usually difficult to achieve at more conserved agonist or ion channel binding sites. Among iGluRs, NMDARs stand out by their numerous allosteric sites conferring to these re- ceptors an exquisite sensitivity to their microenvironment (Dingledine et al. 1999; Paoletti 2011). Extracellular protons and zinc ions, these latter being concentrated at many glutamatergic synapses (Paoletti et al. 2009), provide potent tonic inhibition of NMDARs under physiological conditions (Peters et al. 1987; Westbrook and Mayer 1987; Traynelis and Cull-Candy 1990). In particular, receptors composed of the GluN2A subunit exhibit very high zinc sensitivity, being inhibited by nanomolar zinc concentrations (Fig. 8) (Paoletti et al. 1997). Proton and zinc inhibitions may protect against the deleterious effects of NMDAR overactivation. The amino-terminal region of NMDARs is a major locus for subunit-specific allosteric modulation. This region, the most distal to the membrane, contains clamshell-like domains (the NTDs) that undergo conformational changes that can be sensed by the downstream gating
A

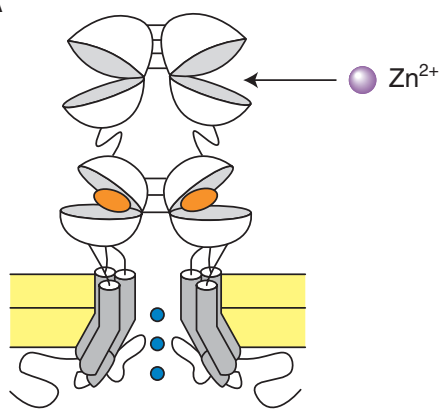

B

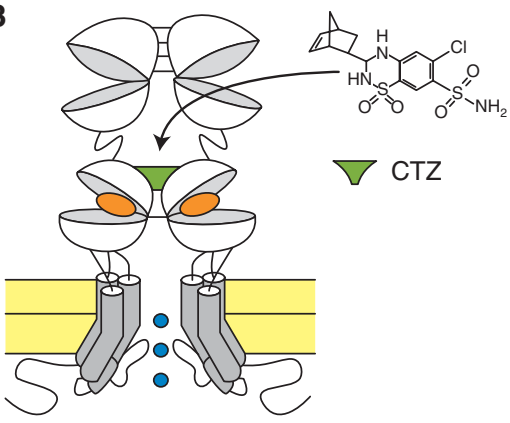

GluN1 + GluN2A
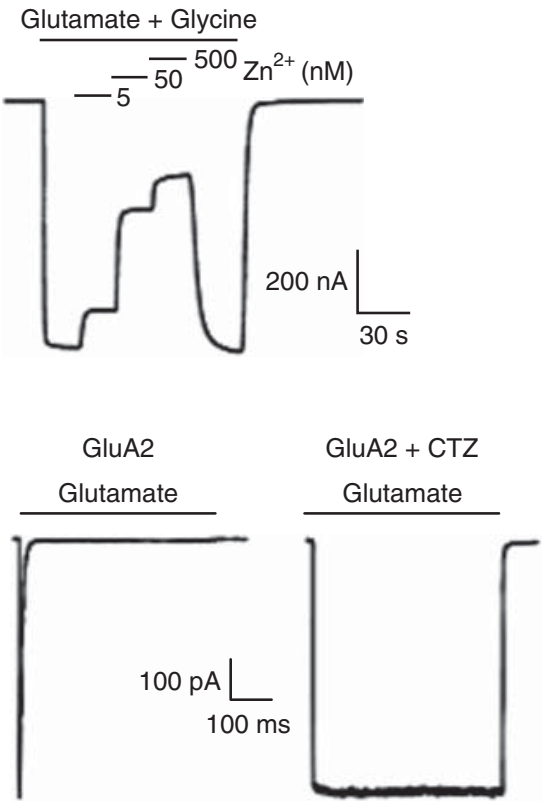

Figure 8. Allosteric modulation of iGluRs. (A) Negative allosteric modulation of NMDARs by extracellular zinc. The GluN2A and GluN2B NTDs form subunit-specific inhibitory zinc-binding sites. (Right) Inhibition by nanomolar zinc concentrations of GluN1/GluN2A responses (adapted from Paoletti et al. 2000). (B) Positive allosteric modulation of AMPARs by cyclothiazide (CTZ). CTZ binds and stabilizes the ABD dimer interface. (Right) CTZ blocks desensitization of GluA2 receptors (Sun et al. 2002). 
machinery (Fig. 8) (Gielen et al. 2008, 2009). In addition to forming inhibitory zinc-binding sites, NMDAR NTDs harbor a site for extracellular polyamines that act as positive allosteric modulators of GluN2B-containing NMDARs (Mony et al. 2011).

At AMPA, kainate, and $\delta$ receptors, a major site of action for allosteric modulators is the dimer interface between two neighboring agonist-binding domains. Compounds like cyclothiazide at AMPARs (Sun et al. 2002), $\mathrm{Na}^{+}$and $\mathrm{Cl}^{-}$ions at kainateRs (Bowie 2002; Plested et al. 2008), or $\mathrm{Ca}^{2+}$ ions at deltaRs (Hansen et al. 2009) all act as positive allosteric modulators by reducing receptor desensitization through stabilization of the ABD-dimer interface (Fig. 8). Positive allosteric modulators of AMPARs are currently evaluated for their ability to restore cognitive dysfunction associated with neurodegenerative conditions (Ward et al. 2010).

\section{Auxiliary Subunits}

Native iGluRs were long believed to be standalone receptors composed of just four poreforming subunits. Recent evidence, however, has established that, in vivo, many membrane proteins interact specifically with iGluRs and influence their function. Notably, single-particle EM analysis of purified native AMPARs from rat brain revealed the existence of a substantial electron density in the transmembrane region not attributable to the receptor ion channel per se but, rather, to tightly associated TARP proteins (for transmembrane AMPAR regulatory proteins) (Nakagawa et al. 2005). TARPs, or stargazing-like proteins, form a large family (six members, $\gamma-2,-3,-4,-5,-7$, and -8 ) of four membrane-spanning segments acting as auxiliary (or accessory) subunits of AMPARs (Jackson and Nicoll, 2011).

Virtually every aspect of AMPAR function is affected by association with TARPs including receptor trafficking and localization, channel conductance and open probability, activation and deactivation kinetics, and sensitivity to allosteric modulators (Priel et al. 2005; Kato et al. 2010; Jackson and Nicoll 2011). The direct interaction of the extracellular loop that con- nects transmembrane segments 1 and 2 of TARPs with extracellular regions of the receptor, including the ABDs, has a primary role in mediating TARP effects on receptor gating and pharmacology (Tomita et al. 2005a). Additional interactions within the membrane or cytoplasm likely play a role in TARP effects on permeation properties. Through their PDZ-binding motif, TARPs are also essential in controlling the number of AMPARs expressed at the synapse (Tomita et al. 2005b; Opazo et al. 2010). The interaction of TARPs with AMPARs is highly dynamic, being regulated in an activity-dependent manner. Thus, receptor desensitization rapidly promotes dissociation of TARP-AMPAR complexes, and this dissociation mechanism contributes to synaptic short-term modulation (Morimoto-Tomita et al. 2009).

TARPs are not the only auxiliary proteins of iGluRs. Proteomic approaches identified cornichon (CNIH2 and 3) (Schwenk et al. 2009) and CKAMP44 (von Engelhardt et al. 2010) as novel auxiliary subunits of AMPARs, and NETO1 $(\mathrm{Ng}$ et al. 2009) and NETO2 (Zhang et al. 2009) as accessory subunits of NMDA and kainate receptors, respectively. The discovery of these families of auxiliary iGluR subunits helps solve the longstanding puzzle of why the functional properties of native iGluRs often do not faithfully match those of iGluRs expressed in heterologous cells. It also raises the enticing possibility that the structural plasticity of iGluR-auxiliary subunit complexes is a major determinant of experiencedependent changes in synaptic efficacy.

\section{CONCLUSION}

The mammalian brain has evolved to rely on two major classes of neurotransmitter receptors for the provision of rapid synaptic excitation and inhibition. It is intriguing that these two classes, which perform an equivalent task-coupling agonist binding to fast opening of a transmembrane pore-have adopted strikingly different structural designs. The most obvious divergence is their subunit stoichiometry with Cys-loop receptors being pentamers, whereas iGluRs are tetramers. Other major differences are transmembrane topology and neurotransmitter 
mode of action, with Cys-loop receptors having external amino and carboxyl termini and relying on neurotransmitter binding at subunit interfaces, whereas iGluRs have an intracellular carboxyl terminus and use individual bilobate domains to capture glutamate. The need for two agonists, glutamate and the coagonist glycine or D-serine, to activate NMDARs is another striking distinction that renders these receptors unique among neurotransmitter receptors. Despite this, similarities between the two receptor classes are also apparent: the reliance on large extracellular domains distal from the membrane for housing neurotransmitter binding sites, the use of helical segments for constructing ion channels, and the presence of specialized intracellular domains acting as the pivots for scaffold proteins and regulatory ports for signaling pathways. The past years have seen an explosion in our knowledge of the structure and function of neurotransmitter-gated receptors, in particular, through crystallographic efforts. We now have realistic structural and mechanistic schemes to explain how Cys-loop and iGluRs receptors have been optimized by evolution so that their thermodynamic and kinetic properties match the strict requirements of fast and reliable synaptic function. Nevertheless, neurotransmittergated receptors are particularly large and complex multimeric molecular machines, and several aspects of their operation, conformational dynamics, interaction with partner proteins, and regulation remain ill defined. The use of a variety of experimental approaches, including structural, biophysical, and electrophysiological techniques, appear more necessary than ever to decipher the intricate functioning of these key signaling molecules.

\section{REFERENCES}

Absalom NL, Lewis TM, Kaplan W, Pierce KD, Schofield PR. 2003. Role of charged residues in coupling ligand binding and channel activation in the extracellular domain of the glycine receptor. J Biol Chem 278: 50151-50157.

Alexander SP, Mathie A, Peters JA. 2008. Guide to receptors and channels (GRAC), 3rd ed. Br J Pharmacol 153 (Suppl 2): $S 1-S 209$.

Amin J, Weiss DS. 1996. Insights into the activation mechanism of $\rho 1$ GABA receptors obtained by coexpression of wild type and activation-impaired subunits. Proc $R$ Soc Lond B Biol Sci 263: 273-282.

Araud T, Wonnacott S, Bertrand D. 2010. Associated proteins: The universal toolbox controlling ligand gated ion channel function. Biochem Pharmacol 80: 160-169.

Arevalo E, Chiara DC, Forman SA, Cohen JB, Miller KW. 2005. Gating-enhanced accessibility of hydrophobic sites within the transmembrane region of the nicotinic acetylcholine receptor's $\delta$-subunit. A time-resolved photolabeling study. J Biol Chem 280: 13631-13640.

Armstrong N, Gouaux E. 2000. Mechanisms for activation and antagonism of an AMPA-sensitive glutamate receptor: Crystal structures of the GluR2 ligand binding core. Neuron 28: 165-181.

Armstrong N, Sun Y, Chen GQ, Gouaux E. 1998. Structure of a glutamate-receptor ligand-binding core in complex with kainate. Nature 395: 913-917.

Armstrong N, Jasti J, Beich-Frandsen M, Gouaux E. 2006. Measurement of conformational changes accompanying desensitization in an ionotropic glutamate receptor. Cell 127: 85-97.

Ascher P, Nowak L. 1988. The role of divalent cations in the $\mathrm{N}$-methyl-D-aspartate responses of mouse central neurones in culture. J Physiol 399: 247-266.

Ashton H, Young AH. 2003. GABA-ergic drugs: Exit stage left, enter stage right. J Psychopharmacol 17: 174-178.

Banks MI, White JA, Pearce RA. 2000. Interactions between distinct $\mathrm{GABA}_{\mathrm{A}}$ circuits in hippocampus. Neuron 25: 449-457.

Barnard EA, Darlison MG, Seeburg P. 1987. Molecular biology of $\mathrm{GABA}_{\mathrm{A}}$ receptor: The receptor/channel superfamily. Trends Neurosci 10: 502-509.

Bartos M, Corradi J, Bouzat C. 2009. Structural basis of activation of Cys-loop receptors: The extracellular-transmembrane interface as a coupling region. Mol Neurobiol 40: $236-252$.

Beato M, Groot-Kormelink PJ, Colquhoun D, Sivilotti LG. 2004. The activation mechanism of $\alpha 1$ homomeric glycine receptors. J Neurosci 24: 895-906.

Beene DL, Brandt GS, Zhong W, Zacharias NM, Lester HA, Dougherty DA. 2002. Cation $-\pi$ interactions in ligand recognition by serotonergic (5-HT3A) and nicotinic acetylcholine receptors: The anomalous binding properties of nicotine. Biochemistry 41: 10262-10269.

Bellone C, Nicoll RA. 2007. Rapid bidirectional switching of synaptic NMDA receptors. Neuron 55: 779-785.

Benveniste M, Mayer ML. 1991. Kinetic analysis of antagonist action at $N$-methyl-D-aspartic acid receptors. Two binding sites each for glutamate and glycine. Biophys $J$ 59: $560-573$.

Bera AK, Akabas MH. 2005. Spontaneous thermal motion of the GABAA receptor M2 channel-lining segments. J Biol Chem 280: 35506-35512.

Bera AK, Chatav M, Akabas MH. 2002. GABA receptor M2-M3 loop secondary structure and changes in accessibility during channel gating. J Biol Chem 277: 4300243010 .

Betz H. 1990. Ligand-gated ion channels in the brain: The amino acid receptor superfamily. Neuron 5: 383-392. 
T.G. Smart and P. Paoletti

Bingol B, Sheng M. 2011. Deconstruction for reconstruction: The role of proteolysis in neural plasticity and disease. Neuron 69: 22-32.

Birdsey-Benson A, Gill A, Henderson LP, Madden DR. 2010. Enhanced efficacy without further cleft closure: Reevaluating twist as a source of agonist efficacy in AMPA receptors. J Neurosci 30: 1463-1470.

Bliss TV, Collingridge GL. 1993. A synaptic model of memory: Long-term potentiation in the hippocampus. Nature 361: $31-39$.

Bocquet N, Nury H, Baaden M, Le Poupon C, Changeux JP, Delarue M, Corringer PJ. 2009. X-ray structure of a pentameric ligand-gated ion channel in an apparently open conformation. Nature 457: 111-114.

Bogdanov Y, Michels G, Armstrong-Gold C, Haydon PG, Lindstrom J, Pangalos M, Moss SJ. 2006. Synaptic GABA receptors are directly recruited from their extrasynaptic counterparts. EMBO J 25: 4381-4389.

Bohme I, Rabe H, Luddens H. 2004. Four amino acids in the $\alpha$ subunits determine the $\gamma$-aminobutyric acid sensitivities of GABAA receptor subtypes. J Biol Chem 279: 35193-35200.

Boileau AJ, Newell JG, Czajkowski C. 2002. GABA $A_{\mathrm{A}}$ receptor B2 Tyr97 and Leu99 line the GABA-binding site. Insights into mechanisms of agonist and antagonist actions. J Biol Chem 277: 2931-2937.

Bourne Y, Talley TT, Hansen SB, Taylor P, Marchot P. 2005. Crystal structure of a Cbtx-AChBP complex reveals essential interactions between snake $\alpha$-neurotoxins and nicotinic receptors. EMBO J 24: 1512-1522.

Bouzat C, Gumilar F, Spitzmaul G, Wang HL, Rayes D, Hansen SB, Taylor P, Sine SM. 2004. Coupling of agonist binding to channel gating in an ACh-binding protein linked to an ion channel. Nature 430: 896-900.

Bowie D. 2002. External anions and cations distinguish between AMPA and kainate receptor gating mechanisms. J Physiol 539: 725-733.

Brannigan G, Henin J, Law R, Eckenhoff R, Klein ML. 2008 Embedded cholesterol in the nicotinic acetylcholine receptor. Proc Natl Acad Sci 105: 14418-14423.

Breitinger HG, Becker CM. 2002. The inhibitory glycine receptor-simple views of a complicated channel. Chembiochem 3: 1042-1052.

Brejc K, van Dijk WJ, Klaassen RV, Schuurmans M, van Der OJ, Smit AB, Sixma TK. 2001. Crystal structure of an ACh-binding protein reveals the ligand-binding domain of nicotinic receptors. Nature 411: 269-276.

Bruneau EG, Esteban JA, Akaaboune M. 2009. Receptorassociated proteins and synaptic plasticity. FASEB J 23: 679-688.

Burnashev N, Schoepfer R, Monyer H, Ruppersberg JP, Gunther W, Seeburg PH, Sakmann B. 1992. Control by asparagine residues of calcium permeability and magnesium blockade in the NMDA receptor. Science 257: 1415-1419.

Burnashev N, Zhou Z, Neher E, Sakmann B. 1995. Fractional calcium currents through recombinant GluR channels of the NMDA, AMPA and kainate receptor subtypes. J Physiol 485: 403-418.

Burnashev N, Villarroel A, Sakmann B. 1996. Dimensions and ion selectivity of recombinant AMPA and kainate re- ceptor channels and their dependence on $\mathrm{Q} / \mathrm{R}$ site residues. J Physiol 496: 165-173.

Carland JE, Moorhouse AJ, Barry PH, Johnston GA, Chebib M. 2004. Charged residues at the $2^{\prime}$ position of human GABAC $\rho 1$ receptors invert ion selectivity and influence open state probability. J Biol Chem 279: 54153-54160.

Cashin AL, Torrice MM, McMenimen KA, Lester HA, Dougherty DA. 2007. Chemical-scale studies on the role of a conserved aspartate in preorganizing the agonist binding site of the nicotinic acetylcholine receptor. Biochemistry 46: 630-639.

Castaldo P, Stefanoni P, Miceli F, Coppola G, Del Giudice EM, Bellini G, Pascotto A, Trudell JR, Harrison NL, Annunziato L, et al. 2004. A novel hyperekplexia-causing mutation in the pre-transmembrane segment 1 of the human glycine receptor $\alpha 1$ subunit reduces membrane expression and impairs gating by agonists. $J$ Biol Chem 279: 25598-25604.

Cederholm J, Schofield P, Lewis T. 2009. Gating mechanisms in Cys-loop receptors. Eur Biophys J 39: 37-49.

Celie PH, van Rossum-Fikkert SE, van Dijk WJ, Brejc K, Smit AB, Sixma TK. 2004. Nicotine and carbamylcholine binding to nicotinic acetylcholine receptors as studied in AChBP crystal structures. Neuron 41: 907-914.

Celie PH, Kasheverov IE, Mordvintsev DY, Hogg RC, van Nierop P, van Elk R, Rossum-Fikkert SE, Zhmak MN, Bertrand D, Tsetlin V, et al. 2005a. Crystal structure of nicotinic acetylcholine receptor homolog AChBP in complex with an $\alpha$-conotoxin PnIA variant. Nat Struct Mol Biol 12: 582-588.

Celie PH, Klaassen RV, Rossum-Fikkert SE, van Elk R, van Nierop P, Smit AB, Sixma TK. 2005b. Crystal structure of acetylcholine-binding protein from Bulinus truncatus reveals the conserved structural scaffold and sites of variation in nicotinic acetylcholine receptors. J Biol Chem 280: $26457-26466$.

Chakrapani S, Bailey TD, Auerbach A. 2003. The role of loop 5 in acetylcholine receptor channel gating. J Gen Physiol 122: $521-539$.

Chang HR, Kuo CC. 2008. The activation gate and gating mechanism of the NMDA receptor. J Neurosci 28: 15461556.

Chang Y, Weiss DS. 1999. Channel opening locks agonist onto the GABA $_{C}$ receptor. Nat Neurosci 2: 219-225.

Chang Y, Weiss DS. 2002. Site-specific fluorescence reveals distinct structural changes with GABA receptor activation and antagonism. Nat Neurosci 5: 1163-1168.

Chang YC, Wu W, Zhang Jl, Huang Y. 2009. Allosteric activation mechanism of the Cys-loop receptors. Acta Pharmacol Sin 30: 663-672.

Charpantier E, Wiesner A, Huh KH, Ogier R, Hoda JC, Allaman G, Raggenbass M, Feuerbach D, Bertrand D, Fuhrer C. 2005. $\alpha 7$ neuronal nicotinic acetylcholine receptors are negatively regulated by tyrosine phosphorylation and Src-family kinases. J Neurosci 25: 9836-9849.

Chen BS, Roche KW. 2007. Regulation of NMDA receptors by phosphorylation. Neuropharmacology 53: 362-368.

Chen GQ, Cui C, Mayer ML, Gouaux E. 1999. Functional characterization of a potassium-selective prokaryotic glutamate receptor. Nature 402: 817-821. 
Christie LA, Russell TA, Xu J, Wood L, Shepherd GM, Contractor A. 2010. AMPA receptor desensitization mutation results in severe developmental phenotypes and early postnatal lethality. Proc Natl Acad Sci 107: 9412-9417.

Chung SK, Vanbellinghen JF, Mullins JG, Robinson A, Hantke J, Hammond CL, Gilbert DF, Freilinger M, Ryan M, Kruer MC, et al. 2010. Pathophysiological mechanisms of dominant and recessive GLRA1 mutations in hyperekplexia. J Neurosci 30: 9612-9620.

Clements JD, Westbrook GL. 1991. Activation kinetics reveal the number of glutamate and glycine binding sites on the N-methyl-D-aspartate receptor. Neuron 7: 605-613.

Clements JD, Feltz A, Sahara Y, Westbrook GL. 1998. Activation kinetics of AMPA receptor channels reveal the number of functional agonist binding sites. J Neurosci 18: 119-127.

Contractor A, Mulle C, Swanson GT. 2011. Kainate receptors coming of age: Milestones of two decades of research. Trends Neurosci 34: 154-163.

Corringer PJ, Bertrand S, Galzi JL, Villers-Thiery A, Changeux JP, Bertrand D. 1999. Mutational analysis of the charge selectivity filter of the $\alpha 7$ nicotinic acetylcholine receptor. Neuron 22: 831-843.

Corringer PJ, Le NN, Changeux JP. 2000. Nicotinic receptors at the amino acid level. Annu Rev Pharmacol Toxicol 40: $431-458$.

Cull-Candy SG, Leszkiewicz DN. 2004. Role of distinct NMDA receptor subtypes at central synapses. Sci STKE 2004: re16.

Cymes GD, Ni Y, Grosman C. 2005. Probing ion-channel pores one proton at a time. Nature 438: 975-980.

Davies PA, Pistis M, Hanna MC, Peters JA, Lambert JJ, Hales TG, Kirkness EF. 1999. The 5-HT3B subunit is a major determinant of serotonin-receptor function. Nature 397: $359-363$.

Davies PA, Wang W, Hales TG, Kirkness EF. 2003. A novel class of ligand-gated ion channel is activated by $\mathrm{Zn}^{2+} . J$ Biol Chem 278: 712-717.

Dingledine R, Borges K, Bowie D, Traynelis SF. 1999. The glutamate receptor ion channels. Pharmacol Rev 51: 7 61.

Endele S, Rosenberger G, Geider K, Popp B, Tamer C, Stefanova I, Milh M, Kortum F, Fritsch A, Pientka FK, et al. 2010. Mutations in GRIN2A and GRIN2B encoding regulatory subunits of NMDA receptors cause variable neurodevelopmental phenotypes. Nat Genet 42: 1021-1026.

Engel AG, Ohno K, Sine SM. 2003. Sleuthing molecular targets for neurological diseases at the neuromuscular junction. Nat Rev Neurosci 4: 339-352.

Feng G, Tintrup H, Kirsch J, Nichol MC, Kuhse J, Betz H, Sanes JR. 1998. Dual requirement for gephyrin in glycine receptor clustering and molybdoenzyme activity. Science 282: $1321-1324$.

Fernandes CC, Berg DK, Gomez-Varela D. 2010. Lateral mobility of nicotinic acetylcholine receptors on neurons is determined by receptor composition, local domain, and cell type. J Neurosci 30: 8841-8851.

Fritschy JM, Harvey RJ, Schwarz G. 2008. Gephyrin: Where do we stand, where do we go? Trends Neurosci 31: 257264.
Furukawa H, Gouaux E. 2003. Mechanisms of activation, inhibition and specificity: Crystal structures of the NMDA receptor NR1 ligand-binding core. EMBO J 22: $2873-$ 2885.

Furukawa H, Singh SK, Mancusso R, Gouaux E. 2005. Subunit arrangement and function in NMDA receptors. $\mathrm{Na}$ ture 438: 185-192.

Galzi JL, Villers-Thiery A, Hussy N, Bertrand S, Changeux JP, Bertrand D. 1992. Mutations in the channel domain of a neuronal nicotinic receptor convert ion selectivity from cationic to anionic. Nature 359: 500-505.

Gardoni F, Marcello E, Di Luca M. 2009. Postsynaptic density-membrane associated guanylate kinase proteins (PSD-MAGUKs) and their role in CNS disorders. Neuroscience 158: 324-333.

Gay EA, Yakel JL. 2007. Gating of nicotinic ACh receptors; new insights into structural transitions triggered by agonist binding that induce channel opening. J Physiol 584: 727-733.

Geitmann M, Retra K, de Kloe GE, Homan E, Smit AB, de Esch IJP, Danielson UH. 2010. Interaction kinetic and structural dynamic analysis of ligand binding to acetylcholine-binding protein. Biochemistry 49: 8143-8154.

Gielen M, Le Goff A, Stroebel D, Johnson JW, Neyton J, Paoletti P. 2008. Structural rearrangements of NR1/NR2A NMDA receptors during allosteric inhibition. Neuron 57: 80-93.

Gielen M, Siegler Retchless B, Mony L, Johnson JW, Paoletti P. 2009. Mechanism of differential control of NMDA receptor activity by NR2 subunits. Nature 459: 703-707.

Gleitsman KR, Kedrowski SM, Lester HA, Dougherty DA. 2008. An intersubunit hydrogen bond in the nicotinic acetylcholine receptor that contributes to channel gating. J Biol Chem 283: 35638-35643.

Grenningloh G, Gundelfinger ED, Schmitt B, Betz H, Darlison MG, Barnard EA, Schofield PR, Seeburg PH. 1987. Glycine vs GABA receptors. Nature 330: 25-26.

Grosman C, Zhou M, Auerbach A. 2000. Mapping the conformational wave of acetylcholine receptor channel gating. Nature 403: 773-776.

Grutter T, Prado de CL, Le NN, Corringer PJ, Edelstein S, Changeux JP. 2003. An H-bond between two residues from different loops of the acetylcholine binding site contributes to the activation mechanism of nicotinic receptors. EMBO J 22: 1990-2003.

Gunthorpe MJ, Lummis SC. 2001. Conversion of the ion selectivity of the 5-HT(3a) receptor from cationic to anionic reveals a conserved feature of the ligand-gated ion channel superfamily. J Biol Chem 276: 10977-10983.

Han NL, Clements JD, Lynch JW. 2004. Comparison of taurine- and glycine-induced conformational changes in the M2-M3 domain of the glycine receptor. J Biol Chem 279: 19559-19565.

Hansen SB, Sulzenbacher G, Huxford T, Marchot P, Taylor P, Bourne Y. 2005. Structures of Aplysia AChBP complexes with nicotinic agonists and antagonists reveal distinctive binding interfaces and conformations. EMBO J 24: 3635-3646.

Hansen KB, Yuan H, Traynelis SF. 2007. Structural aspects of AMPA receptor activation, desensitization and deactivation. Curr Opin Neurobiol 17: 281-288. 
Hansen SB, Wang HL, Taylor P, Sine SM. 2008. An ion selectivity filter in the extracellular domain of Cys-loop receptors reveals determinants for ion conductance. J Biol Chem 283: 36066-36070.

Hansen KB, Naur P, Kurtkaya NL, Kristensen AS, Gajhede M, Kastrup JS, Traynelis SF. 2009. Modulation of the dimer interface at ionotropic glutamate-like receptor $\delta 2$ by D-serine and extracellular calcium. J Neurosci 29: 907-917.

Harvey RJ, Thomas P, James CH, Wilderspin A, Smart TG. 1999. Identification of an inhibitory $\mathrm{Zn}^{2+}$ binding site on the human glycine receptor $\alpha 1$ subunit. J Physiol 520: 53-64.

Henson MA, Roberts AC, Perez-Otano I, Philpot BD. 2010. Influence of the NR3A subunit on NMDA receptor functions. Prog Neurobiol 91: 23-37.

Hibbs RE, Gouaux E. 2011. Principles of activation and permeation in an anion-selective Cys-loop receptor. Nature 474: $54-60$.

Hilf RJC, Dutzler R. 2008. X-ray structure of a prokaryotic pentameric ligand-gated ion channel. Nature 452: $375-$ 379.

Hilf RJC, Dutzler R. 2009. Structure of a potentially open state of a proton-activated pentameric ligand-gated ion channel. Nature 457: 115-118.

Hollmann M, O’Shea-Greenfield A, Rogers SW, Heinemann S. 1989. Cloning by functional expression of a member of the glutamate receptor family. Nature 342: 643-648.

Hu XQ, Zhang L, Stewart RR, Weight FF. 2003. Arginine 222 in the pre-transmembrane domain 1 of 5 -HT3A receptors links agonist binding to channel gating. J Biol Chem 278: 46583-46589.

Hume RI, Dingledine R, Heinemann SF. 1991. Identification of a site in glutamate receptor subunits that controls calcium permeability. Science 253: 1028-1031.

Imoto K, Busch C, Sakmann B, Mishina M, Konno T, Nakai J, Bujo H, Mori Y, Fukuda K, Numa S. 1988. Rings of negatively charged amino acids determine the acetylcholine receptor channel conductance. Nature 335: 645-648.

Inanobe A, Furukawa H, Gouaux E. 2005. Mechanism of partial agonist action at the NR1 subunit of NMDA receptors. Neuron 47: 71-84.

Isaac JT, Ashby M, McBain CJ. 2007. The role of the GluR2 subunit in AMPA receptor function and synaptic plasticity. Neuron 54: 859-871.

Jackson AC, Nicoll RA. 2011. The expanding social network of ionotropic glutamate receptors: TARPs and other transmembrane auxiliary subunits. Neuron 70: 178-199.

Jacob TC, Moss SJ, Jurd R. 2008. GABA A receptor trafficking and its role in the dynamic modulation of neuronal inhibition. Nat Rev Neurosci 9: 331-343.

Janovjak H, Sandoz G, Isacoff EY. 2011. A modern ionotropic glutamate receptor with a $\mathrm{K}^{+}$selectivity signature sequence. Nat Commun 2: 232.

Jensen ML, Timmermann DB, Johansen TH, Schousboe A, Varming T, Ahring PK. 2002. The $\beta$ subunit determines the ion selectivity of the $\mathrm{GABA}_{\mathrm{A}}$ receptor. J Biol Chem 277: 41438-41447.

Jin R, Banke TG, Mayer ML, Traynelis SF, Gouaux E. 2003. Structural basis for partial agonist action at ionotropic glutamate receptors. Nat Neurosci 6: 803-810.
Jonas P, Burnashev N. 1995. Molecular mechanisms controlling calcium entry through AMPA-type glutamate receptor channels. Neuron 15: 987-990.

Jones MV, Westbrook GL. 1996. The impact of receptor desensitization on fast synaptic transmission. Trends Neurosci 19: 96-101.

Karlin A, Akabas MH. 1995. Toward a structural basis for the function of nicotinic acetylcholine receptors and their cousins. Neuron 15: 1231-1244.

Kash TL, Jenkins A, Kelley JC, Trudell JR, Harrison NL. 2003. Coupling of agonist binding to channel gating in the $\mathrm{GABA}_{\mathrm{A}}$ receptor. Nature 421: 272-275.

Kato AS, Gill MB, Yu H, Nisenbaum ES, Bredt DS. 2010. TARPs differentially decorate AMPA receptors to specify neuropharmacology. Trends Neurosci 33: 241-248.

Kawahara Y, Ito K, Sun H, Aizawa H, Kanazawa I, Kwak S. 2004. Glutamate receptors: RNA editing and death of motor neurons. Nature 427: 801.

Kelley SP, Dunlop JI, Kirkness EF, Lambert JJ, Peters JA. 2003. A cytoplasmic region determines single-channel conductance in 5-HT3 receptors. Nature 424: 321-324.

Keramidas A, Moorhouse AJ, French CR, Schofield PR, Barry PH. 2000. M2 pore mutations convert the glycine receptor channel from being anion- to cation-selective. Biophys J 79: 247-259.

Keramidas A, Moorhouse AJ, Pierce KD, Schofield PR, Barry PH. 2002. Cation-selective mutations in the M2 domain of the inhibitory glycine receptor channel reveal determinants of ion-charge selectivity. J Gen Physiol 119: 393-410.

Keramidas A, Moorhouse AJ, Schofield PR, Barry PH. 2004. Ligand-gated ion channels: Mechanisms underlying ion selectivity. Prog Biophys Mol Biol 86: 161-204.

Khatri A, Weiss DS. 2010. The role of loop F in the activation of the GABA receptor. J Physiol 588: 59-66.

Khatri A, Sedelnikova A, Weiss DS. 2009. Structural rearrangements in loop $F$ of the GABA receptor signal ligand binding, not channel activation. Biophys J 96: 45-55.

Kim E, Sheng M. 2004. PDZ domain proteins of synapses. Nat Rev Neurosci 5: 771-781.

Kneussel M, Betz H. 2000. Receptors, gephyrin and gephyrin-associated proteins: Novel insights into the assembly of inhibitory postsynaptic membrane specializations. J Physiol 525: 1-9.

Kohda K, Wang Y, Yuzaki M. 2000. Mutation of a glutamate receptor motif reveals its role in gating and $\delta 2$ receptor channel properties. Nat Neurosci 3: 315-322.

Köhr G. 2006. NMDA receptor function: Subunit composition versus spatial distribution. Cell Tissue Res 326: 439446.

Kuner T, Beck C, Sakmann B, Seeburg PH. 2001. Channellining residues of the AMPA receptor M2 segment: Structural environment of the $\mathrm{Q} / \mathrm{R}$ site and identification of the selectivity filter. J Neurosci 21: 4162-4172.

Langosch D, Laube B, Rundstrom N, Schmieden V, Bormann J, Betz H. 1994. Decreased agonist affinity and chloride conductance of mutant glycine receptors associated with human hereditary hyperekplexia. $E M B O J$ 13: 4223-4228. 
Lape R, Colquhoun D, Sivilotti LG. 2008. On the nature of partial agonism in the nicotinic receptor superfamily. Nature 454: 722-727.

Lau CG, Zukin RS. 2007. NMDA receptor trafficking in synaptic plasticity and neuropsychiatric disorders. Nat Rev Neurosci 8: 413-426.

Lee WY, Sine SM. 2004. Invariant aspartic acid in muscle nicotinic receptor contributes selectively to the kinetics of agonist binding. J Gen Physiol 124: 555-567.

Lee WY, Sine SM. 2005. Principal pathway coupling agonist binding to channel gating in nicotinic receptors. Nature 438: $243-247$.

Lee Y, Rudell J, Yechikhov S, Taylor R, Swope S, Ferns M. 2008. Rapsyn carboxyl terminal domains mediate muscle specific kinase-induced phosphorylation of the muscle acetylcholine receptor. Neuroscience 153: 997-1007.

Lee WY, Free CR, Sine SM. 2009. Binding to gating transduction in nicotinic receptors: Cys-loop energetically couples to pre-M1 and M2-M3 regions. J Neurosci 29: 3189-3199.

Lerma J. 2006. Kainate receptor physiology. Curr Opin Pharmacol 6: 89-97.

Lester HA, Dibas MI, Dahan DS, Leite JF, Dougherty DA. 2004. Cys-loop receptors: New twists and turns. Trends Neurosci 27: 329-336.

Liu SQ, Cull-Candy SG. 2000. Synaptic activity at calciumpermeable AMPA receptors induces a switch in receptor subtype. Nature 405: 454-458.

Loebrich S, Bahring R, Katsuno T, Tsukita S, Kneussel M. 2006. Activated radixin is essential for GABAA receptor $\alpha 5$ subunit anchoring at the actin cytoskeleton. EMBO J 25: 987-999.

Luscher B, Keller CA. 2004. Regulation of $\mathrm{GABA}_{\mathrm{A}}$ receptor trafficking, channel activity, and functional plasticity of inhibitory synapses. Pharmacol Ther 102: 195-221.

Luscher B, Fuchs T, Kilpatrick C. 2011. GABA receptor trafficking-mediated plasticity of inhibitory synapses. Neuron 70: 385-409.

Lyford LK, Sproul AD, Eddins D, McLaughlin JT, Rosenberg RL. 2003. Agonist-induced conformational changes in the extracellular domain of $\alpha 7$ nicotinic acetylcholine receptors. Mol Pharmacol 64: 650-658.

MacDonald RL, Gallagher MJ, Feng HJ, Kang J. 2004. GABAA receptor epilepsy mutations. Biochem Pharmacol 68: 1497-1506.

Madden DR. 2002. The structure and function of glutamate receptor ion channels. Nat Rev Neurosci 3: 91-101.

Mameli M, Balland B, Lujan R, Luscher C. 2007. Rapid synthesis and synaptic insertion of GluR2 for mGluR-LTD in the ventral tegmental area. Science 317: 530-533.

Mayer ML. 2005. Crystal structures of the GluR5 and GluR6 ligand binding cores: Molecular mechanisms underlying kainate receptor selectivity. Neuron 45: 539-552.

Mayer ML. 2006. Glutamate receptors at atomic resolution. Nature 440: 456-462.

Mayer ML, Armstrong N. 2004. Structure and function of glutamate receptor ion channels. Annu Rev Physiol 66: $161-181$.
Mayer ML, Westbrook GL, Guthrie PB. 1984. Voltagedependent block by $\mathrm{Mg}^{2+}$ of NMDA responses in spinal cord neurones. Nature 309: 261-263.

Mercado J, Czajkowski C. 2006. Charged residues in the $\alpha 1$ and $\beta 2$ pre-M1 regions involved in $\mathrm{GABA}_{\mathrm{A}}$ receptor activation. J Neurosci 26: 2031-2040.

Miller PS, Smart TG. 2010. Binding, activation and modulation of Cys-loop receptors. Trends Pharmacol Sci 31: $161-174$.

Miller PS, Beato M, Harvey RJ, Smart TG. 2005. Molecular determinants of glycine receptor $\alpha \beta$ subunit sensitivities to $\mathrm{Zn}^{2+}$-mediated inhibition. J Physiol 566: 657-670.

Miller PS, Topf M, Smart TG. 2008. Mapping a molecular link between allosteric inhibition and activation of the glycine receptor. Nat Struct Mol Biol 15: 1084-1093.

Milstein AD, Nicoll RA. 2008. Regulation of AMPA receptor gating and pharmacology by TARP auxiliary subunits. Trends Pharmacol Sci 29: 333-339.

Miyazawa A, Fujiyoshi Y, Unwin N. 2003. Structure and gating mechanism of the acetylcholine receptor pore. Nature 424: 949-955.

Montgomery JM, Zamorano PL, Garner CC. 2004. MAGUKs in synapse assembly and function: An emerging view. Cell Mol Life Sci 61: 911-929.

Mony L, Kew JN, Gunthorpe MJ, Paoletti P. 2009. Allosteric modulators of NR2B-containing NMDA receptors: Molecular mechanisms and therapeutic potential. Br J Pharmacol 157: 1301-1317.

Mony L, Zhu S, Carvalho S, Paoletti P. 2011. Molecular basis of positive allosteric modulation of GluN2B NMDA receptors by polyamines. EMBO J 30: 3134-3146.

Monyer H, Seeburg PH, Wisden W. 1991. Glutamate-operated channels: Developmentally early and mature forms arise by alternative splicing. Neuron 6: 799-810.

Moorhouse AJ, Keramidas A, Zaykin A, Schofield PR, Barry PH. 2002. Single channel analysis of conductance and rectification in cation-selective, mutant glycine receptor channels. J Gen Physiol 119: 411-425.

Mori H, Masaki H, Yamakura T, Mishina M. 1992. Identification by mutagenesis of a $\mathrm{Mg}^{2+}$-block site of the NMDA receptor channel. Nature 358: 673-675.

Morimoto-Tomita M, Zhang W, Straub C, Cho CH, Kim KS, Howe JR, Tomita S. 2009. Autoinactivation of neuronal AMPA receptors via glutamate-regulated TARP interaction. Neuron 61: 101-112.

Moss SJ, Smart TG. 1996. Modulation of amino acid-gated ion channels by protein phosphorylation. Int Rev Neurobiol 39: 1-52.

Moss SJ, Smart TG. 2001. Constructing inhibitory synapses. Nat Rev Neurosci 2: 240-250.

Mu TW, Lester HA, Dougherty DA. 2003. Different binding orientations for the same agonist at homologous receptors: A lock and key or a simple wedge? J Am Chem Soc 125: $6850-6851$.

Mukhtasimova N, Sine SM. 2007. An intersubunit trigger of channel gating in the muscle nicotinic receptor. J Neurosci 27: 4110-4119.

Mukhtasimova N, Free C, Sine SM. 2005. Initial coupling of binding to gating mediated by conserved residues in the muscle nicotinic receptor. J Gen Physiol 126: 23-39. 
Mukhtasimova N, Lee WY, Wang HL, Sine SM. 2009. Detection and trapping of intermediate states priming nicotinic receptor channel opening. Nature 459: 451-454.

Nakagawa T, Cheng Y, Ramm E, Sheng M, Walz T. 2005. Structure and different conformational states of native AMPA receptor complexes. Nature 433: 545-549.

Nakanishi S, Masu M. 1994. Molecular diversity and functions of glutamate receptors. Annu Rev Biophys Biomol Struct 23: 319-348.

Neff RA III, Gomez-Varela D, Fernandes CC, Berg DK. 2009. Postsynaptic scaffolds for nicotinic receptors on neurons. Acta Pharmacol Sin 30: 694-701.

Nevin ST, Cromer BA, Haddrill JL, Morton CJ, Parker MW, Lynch JW. 2003. Insights into the structural basis for zinc inhibition of the glycine receptor. J Biol Chem 278: 28985-28992.

Newell JG, Czajkowski C. 2003. The GABAA receptor $\alpha 1$ subunit Pro ${ }^{174}-$ Asp $^{191}$ segment is involved in GABA binding and channel gating. J Biol Chem 278: 1316613172.

Newell JG, McDevitt RA, Czajkowski C. 2004. Mutation of glutamate 155 of the GABAA receptor $\beta 2$ subunit produces a spontaneously open channel: A trigger for channel activation. J Neurosci 24: 11226-11235.

Ng D, Pitcher GM, Szilard RK, Sertie A, Kanisek M, Clapcote SJ, Lipina T, Kalia LV, Joo D, McKerlie C, et al. 2009. Netol is a novel CUB-domain NMDA receptorinteracting protein required for synaptic plasticity and learning. PLoS Biol 7: e41.

Nowak L, Bregestovski P, Ascher P, Herbet A, Prochiantz A. 1984. Magnesium gates glutamate-activated channels in mouse central neurones. Nature 307: 462-465.

Opazo P, Labrecque S, Tigaret CM, Frouin A, Wiseman PW, De Koninck P, Choquet D. 2010. CaMKII triggers the diffusional trapping of surface AMPARs through phosphorylation of stargazin. Neuron 67: 239-252.

Ortells MO, Lunt GG. 1995. Evolutionary history of the ligand-gated ion-channel superfamily of receptors. Trends Neurosci 18: 121-127.

Paas Y, Gibor G, Grailhe R, Savatier-Duclert N, Dufresne V, Sunesen M, de Carvalho LP, Changeux JP, Attali B. 2005. Pore conformations and gating mechanism of a Cys-loop receptor. Proc Natl Acad Sci 102: 15877-15882.

Padgett CL, Hanek AP, Lester HA, Dougherty DA, Lummis SCR. 2007. Unnatural amino acid mutagenesis of the $\mathrm{GABA}_{\mathrm{A}}$ receptor binding site residues reveals a novel cation $-\pi$ interaction between GABA and $\beta 2$ Tyr97. J Neurosci 27: 886-892.

Paoletti P. 2011. Molecular basis of NMDA receptor functional diversity. Eur J Neurosci 33: 1351-1365.

Paoletti P, Ascher P, Neyton J. 1997. High-affinity zinc inhibition of NMDA NR1-NR2A receptors. J Neurosci 17: 5711-5725.

Paoletti P, Perin-Dureau F, Fayyazuddin A, Le Goff A, Callebaut I, Neyton J. 2000. Molecular organization of a zinc binding $\mathrm{N}$-terminal modulatory domain in a NMDA receptor subunit. Neuron 28: 911-925.

Paoletti P, Vergnano AM, Barbour B, Casado M. 2009. Zinc at glutamatergic synapses. Neuroscience 158: 126-136.
Peters S, Koh J, Choi DW. 1987. Zinc selectively blocks the action of $N$-methyl-D-aspartate on cortical neurons. Science 236: 589-593.

Peters JA, Hales TG, Lambert JJ. 2005. Molecular determinants of single-channel conductance and ion selectivity in the Cys-loop family: Insights from the 5-HT3 receptor. Trends Pharmacol Sci 26: 587-594.

Piña-Crespo JC, Talantova M, Micu I, States B, Chen HS, Tu S, Nakanishi N, Tong G, Zhang D, Heinemann SF, et al. 2010. Excitatory glycine responses of CNS myelin mediated by NR1/NR3 "NMDA" receptor subunits. J Neurosci 30: 11501-11505.

Pless SA, Millen KS, Hanek AP, Lynch JW, Lester HA, Lummis SCR, Dougherty DA. 2008. A cation $-\pi$ interaction in the binding site of the glycine receptor is mediated by a phenylalanine residue. J Neurosci 28: 10937-10942.

Plested AJ, Vijayan R, Biggin PC, Mayer ML. 2008. Molecular basis of kainate receptor modulation by sodium. $\mathrm{Neu}$ ron 58: 720-735.

Pohlsgaard J, Frydenvang K, Madsen U, Kastrup JS. 2011. Lessons from more than 80 structures of the GluA2 ligand-binding domain in complex with agonists, antagonists and allosteric modulators. Neuropharmacology 60: $135-150$.

Price KL, Millen KS, Lummis SCR. 2007. Transducing agonist binding to channel gating involves different interactions in 5-HT3 and GABAC Receptors. J Biol Chem 282: 25623-25630.

Priel A, Kolleker A, Ayalon G, Gillor M, Osten P, Stern-Bach Y. 2005. Stargazin reduces desensitization and slows deactivation of the AMPA-type glutamate receptors. J Neurosci 25: 2682-2686.

Purohit P, Auerbach A. 2007. Acetylcholine receptor gating: Movement in the $\alpha$-subunit extracellular domain. J Gen Physiol 130: 569-579.

Purohit P, Mitra A, Auerbach A. 2007. A stepwise mechanism for acetylcholine receptor channel gating. Nature 446: 930-933.

Rogers M, Dani JA. 1995. Comparison of quantitative calcium flux through NMDA, ATP, and ACh receptor channels. Biophys J 68: 501-506.

Rosenmund C, Stern-Bach Y, Stevens CF. 1998. The tetrameric structure of a glutamate receptor channel. Science 280: 1596-1599.

Rossmann M, Sukumaran M, Penn AC, Veprintsev DB, Babu MM, Greger IH. 2011. Subunit-selective N-terminal domain associations organize the formation of AMPA receptor heteromers. EMBO J 30: 959-971.

Sakurada K, Masu M, Nakanishi S. 1993. Alteration of $\mathrm{Ca}^{2+}$ permeability and sensitivity to $\mathrm{Mg}^{2+}$ and channel blockers by a single amino acid substitution in the $N$-methylD-aspartate receptor. J Biol Chem 268: 410-415.

Salter MW, Kalia LV. 2004. Src kinases: A hub for NMDA receptor regulation. Nat Rev Neurosci 5: 317-328.

Sassoe-Pognetto M, Fritschy JM. 2000. Mini-review: Gephyrin, a major postsynaptic protein of GABAergic synapses. Eur J Neurosci 12: 2205-2210.

Schmid SM, Korber C, Herrmann S, Werner M, Hollmann M. 2007. A domain linking the AMPA receptor agonist binding site to the ion pore controls gating and causes 
Lurcher properties when mutated. J Neurosci 27: 1223012241.

Schmid SM, Kott S, Sager C, Huelsken T, Hollmann M. 2009. The glutamate receptor subunit $\delta 2$ is capable of gating its intrinsic ion channel as revealed by ligand binding domain transplantation. Proc Natl Acad Sci 106: 10320-10325.

Schneggenburger R. 1996. Simultaneous measurement of $\mathrm{Ca}^{2+}$ influx and reversal potentials in recombinant $N$-methyl-D-aspartate receptor channels. Biophys J 70: 2165-2174.

Schorge S, Elenes S, Colquhoun D. 2005. Maximum likelihood fitting of single channel NMDA activity with a mechanism composed of independent dimers of subunits. J Physiol 569: 395-418.

Schwenk J, Harmel N, Zolles G, Bildl W, Kulik A, Heimrich B, Chisaka O, Jonas P, Schulte U, Fakler B, et al. 2009. Functional proteomics identify cornichon proteins as auxiliary subunits of AMPA receptors. Science 323: 1313-1319.

Sedelnikova A, Smith CD, Zakharkin SO, Davis D, Weiss DS, Chang Y. 2005. Mapping the $\rho 1$ GABAC receptor agonist binding pocket. Constructing a complete model. J Biol Chem 280: 1535-1542.

Seeburg PH. 1993. The TINS/TiPS Lecture. The molecular biology of mammalian glutamate receptor channels. Trends Neurosci 16: 359-365.

Seeburg PH, Hartner J. 2003. Regulation of ion channel/ neurotransmitter receptor function by RNA editing. Curr Opin Neurobiol 13: 279-283.

Sheng M, Hoogenraad CC. 2007. The postsynaptic architecture of excitatory synapses: A more quantitative view. Annu Rev Biochem 76: 823-847.

Shepherd JD, Huganir RL. 2007. The cell biology of synaptic plasticity: AMPA receptor trafficking. Annu Rev Cell Dev Biol 23: 613-643.

Shi Y, Lu W, Milstein AD, Nicoll RA. 2009. The stoichiometry of AMPA receptors and TARPs varies by neuronal cell type. Neuron 62: 633-640.

Smit AB, Syed NI, Schaap D, Van Minnen J, Klumperman J, Kits KS, Lodder H, Der Schors RC, van Elk R, Sorgedrager B, et al. 2001. A glia-derived acetylcholine-binding protein that modulates synaptic transmission. Nature 411: $261-268$.

Smith TC, Howe JR. 2000. Concentration-dependent substate behavior of native AMPA receptors. Nat Neurosci 3: 992-997.

Sobolevsky AI, Rosconi MP, Gouaux E. 2009. X-ray structure, symmetry and mechanism of an AMPA-subtype glutamate receptor. Nature 462: 745-756.

Sommer B, Kohler M, Sprengel R, Seeburg PH. 1991. RNA editing in brain controls a determinant of ion flow in glutamate-gated channels. Cell 67: 11-19.

Stern-Bach Y, Russo S, Neuman M, Rosenmund C. 1998. A point mutation in the glutamate binding site blocks desensitization of AMPA receptors. Neuron 21: 907-918.

Sun Y, Olson R, Horning M, Armstrong N, Mayer M, Gouaux E. 2002. Mechanism of glutamate receptor desensitization. Nature 417: 245-253.

Talukder I, Borker P, Wollmuth LP. 2010. Specific sites within the ligand-binding domain and ion channel link- ers modulate NMDA receptor gating. J Neurosci 30: 11792-11804.

Thomas P, Mortensen M, Hosie AM, Smart TG. 2005. Dynamic mobility of functional $\mathrm{GABA}_{\mathrm{A}}$ receptors at inhibitory synapses. Nat Neurosci 8: 889-897.

Tichelaar W, Safferling M, Keinanen K, Stark H, Madden DR. 2004. The three-dimensional structure of an ionotropic glutamate receptor reveals a dimer-of-dimers assembly. J Mol Biol 344: 435-442.

Todorovic J, Welsh BT, Bertaccini EJ, Trudell JR, Mihic SJ. 2010. Disruption of an intersubunit electrostatic bond is a critical step in glycine receptor activation. Proc Natl Acad Sci 107: 7987-7992.

Tomita S, Adesnik H, Sekiguchi M, Zhang W, Wada K, Howe JR, Nicoll RA, Bredt DS. 2005a. Stargazin modulates AMPA receptor gating and trafficking by distinct domains. Nature 435: 1052-1058.

Tomita S, Stein V, Stocker TJ, Nicoll RA, Bredt DS. 2005b. Bidirectional synaptic plasticity regulated by phosphorylation of stargazin-like TARPs. Neuron 45: 269-277.

Torres VI, Weiss DS. 2002. Identification of a tyrosine in the agonist binding site of the homomeric $\rho 1 \gamma$-aminobutyric acid (GABA) receptor that, when mutated, produces spontaneous opening. J Biol Chem 277: 43741-43748.

Traynelis SF, Cull-Candy SG. 1990. Proton inhibition of $\mathrm{N}$-methyl-D-aspartate receptors in cerebellar neurons. Nature 345: 347-350.

Traynelis SF, Wollmuth LP, McBain CJ, Menniti FS, Vance KM, Ogden KK, Hansen KB, Yuan H, Myers SJ, Dingledine R, et al. 2010. Glutamate receptor ion channels: Structure, regulation, and function. Pharmacol Rev 62: 405-496.

Triller A, Choquet D. 2005. Surface trafficking of receptors between synaptic and extrasynaptic membranes: And yet they do move! Trends Neurosci 28: 133-139.

Tyagarajan SK, Fritschy JM. 2010. $\mathrm{GABA}_{\mathrm{A}}$ receptors, gephyrin and homeostatic synaptic plasticity. J Physiol 588: $101-106$.

Ulbrich MH, Isacoff EY. 2007. Subunit counting in membrane-bound proteins. Nat Methods 4: 319-321.

Unwin N. 2005. Refined structure of the nicotinic acetylcholine receptor at $4 \AA ̊$ resolution. J Mol Biol 346: 967-989.

Verdoorn TA, Burnashev N, Monyer H, Seeburg PH, Sakmann B. 1991. Structural determinants of ion flow through recombinant glutamate receptor channels. Science 252: 1715-1718.

Villarroel A, Burnashev N, Sakmann B. 1995. Dimensions of the narrow portion of a recombinant NMDA receptor channel. Biophys J 68: 866-875.

von Engelhardt J, Mack V, Sprengel R, Kavenstock N, Li KW, Stern-Bach Y, Smit AB, Seeburg PH, Monyer H. 2010. CKAMP44: A brain-specific protein attenuating shortterm synaptic plasticity in the dentate gyrus. Science 327: $1518-1522$.

Wallace BG, Qu Z, Huganir RL. 1991. Agrin induces phosphorylation of the nicotinic acetylcholine receptor. Neuron 6: 869-878.

Wang CT, Zhang HG, Rocheleau TA, ffrench-Constant RH, Jackson MB. 1999. Cation permeability and cationanion interactions in a mutant GABA-gated chloride channel from Drosophila. Biophys J 77: 691-700. 


\section{T.G. Smart and P. Paoletti}

Wang Q, Pless SA, Lynch JW. 2010. Ligand- and subunitspecific conformational changes in the ligand-binding domain and the TM2-TM3 linker of a1b2g2 $\mathrm{GABA}_{\mathrm{A}}$ receptors. J Biol Chem 285: 40373-40386.

Ward SE, Bax BD, Harries M. 2010. Challenges for and current status of research into positive modulators of AMPA receptors. Br J Pharmacol 160: 181-190.

Watkins JC, Jane DE. 2006. The glutamate story. Br J Pharmacol 147 (Suppl 1): S100-S108.

Wenthold RJ, Prybylowski K, Standley S, Sans N, Petralia RS. 2003. Trafficking of NMDA receptors. Annu Rev Pharmacol Toxicol 43: 335-358.

Westbrook GL, Mayer ML. 1987. Micromolar concentrations of $\mathrm{Zn}^{2+}$ antagonize NMDA and GABA responses of hippocampal neurons. Nature 328: 640-643.

White BH, Cohen JB. 1992. Agonist-induced changes in the structure of the acetylcholine receptor M2 regions revealed by photoincorporation of an uncharged nicotinic noncompetitive antagonist. J Biol Chem 267: 1577015783.

Wick MJ, Mihic SJ, Ueno S, Mascia MP, Trudell JR, Brozowski SJ, Ye Q, Harrison NL, Harris RA. 1998. Mutations of $\gamma$-aminobutyric acid and glycine receptors change alcohol cutoff: Evidence for an alcohol receptor? Proc Natl Acad Sci 95: 6504-6509.

Wo ZG, Oswald RE. 1995. Unraveling the modular design of glutamate-gated ion channels. Trends Neurosci 18: 161-168.

Wollmuth LP, Sobolevsky AI. 2004. Structure and gating of the glutamate receptor ion channel. Trends Neurosci 27: $321-328$.

Wotring VE, Miller TS, Weiss DS. 2003. Mutations at the GABA receptor selectivity filter: A possible role for effective charges. J Physiol 548: 527-540.

Xiu X, Hanek AP, Wang J, Lester HA, Dougherty DA. 2005. A unified view of the role of electrostatic interactions in modulating the gating of Cys loop receptors. $J$ Biol Chem 280: 41655-41666.

Xiu X, Puskar NL, Shanata JAP, Lester HA, Dougherty DA. 2009. Nicotine binding to brain receptors requires a strong cation $-\pi$ interaction. Nature 458: $534-537$.

Yao Y, Harrison CB, Freddolino PL, Schulten K, Mayer ML. 2008. Molecular mechanism of ligand recognition by NR3 subtype glutamate receptors. EMBO J 27: 2158-2170.

Yelshansky MV, Sobolevsky AI, Jatzke C, Wollmuth LP. 2004. Block of AMPA receptor desensitization by a point mutation outside the ligand-binding domain. J Neurosci 24: 4728-4736.

Young GT, Broad LM, Zwart R, Astles PC, Bodkin M, Sher E, Millar NS. 2007. Species selectivity of a nicotinic acetylcholine receptor agonist is conferred by two adjacent extracellular $\beta 4$ amino acids that are implicated in the coupling of binding to channel gating. Mol Pharmacol 71: 389-397.

Zarei MM, Dani JA. 1995. Structural basis for explaining open-channel blockade of the NMDA receptor. J Neurosci 15: $1446-1454$.

Zhang W, St-Gelais F, Grabner CP, Trinidad JC, Sumioka A, Morimoto-Tomita M, Kim KS, Straub C, Burlingame AL, Howe JR, et al. 2009. A transmembrane accessory subunit that modulates kainate-type glutamate receptors. Neuron 61: 385-396.

Zhong W, Gallivan JP, Zhang Y, Li L, Lester HA, Dougherty DA. 1998. From ab initio quantum mechanics to molecular neurobiology: A cation $-\pi$ binding site in the nicotinic receptor. Proc Natl Acad Sci 95: 1208812093.

Zuo J, De Jager PL, Takahashi KA, Jiang W, Linden DJ, Heintz N. 1997. Neurodegeneration in Lurcher mice caused by mutation in $\delta 2$ glutamate receptor gene. Nature 388: 769-773. 


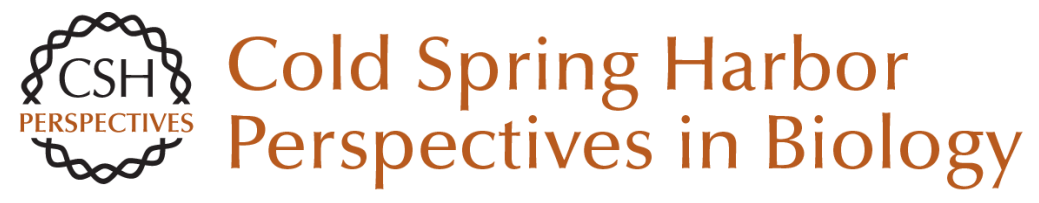

\section{Synaptic Neurotransmitter-Gated Receptors}

Trevor G. Smart and Pierre Paoletti

Cold Spring Harb Perspect Biol 2012; doi: 10.1101/cshperspect.a009662 originally published online January 10, 2012

\section{Subject Collection The Synapse}

Studying Signal Transduction in Single Dendritic Spines Ryohei Yasuda

Synaptic Vesicle Pools and Dynamics AbdulRasheed A. Alabi and Richard W. Tsien

Synapses and Memory Storage Mark Mayford, Steven A. Siegelbaum and Eric $R$. Kandel

Synapses and Alzheimer's Disease Morgan Sheng, Bernardo L. Sabatini and Thomas C. Südhof

Synaptic Cell Adhesion Markus Missler, Thomas C. Südhof and Thomas Biederer

Synaptic Dysfunction in Neurodevelopmental Disorders Associated with Autism and Intellectual Disabilities

Huda Y. Zoghbi and Mark F. Bear

The Postsynaptic Organization of Synapses Morgan Sheng and Eunjoon Kim

Presynaptic LTP and LTD of Excitatory and Inhibitory Synapses

Pablo E. Castillo
Synaptic Vesicle Endocytosis

Yasunori Saheki and Pietro De Camilli

Short-Term Presynaptic Plasticity Wade G. Regehr

NMDA Receptor-Dependent Long-Term

Potentiation and Long-Term Depression

(LTP/LTD) Christian Lüscher and Robert C. Malenka

Ultrastructure of Synapses in the Mammalian

Brain Kristen M. Harris and Richard J. Weinberg

Calcium Signaling in Dendritic Spines Michael J. Higley and Bernardo L. Sabatini

Synaptic Neurotransmitter-Gated Receptors Trevor G. Smart and Pierre Paoletti

Synaptic Vesicle Exocytosis

Thomas C. Südhof and Josep Rizo

Vesicular and Plasma Membrane Transporters for Neurotransmitters

Randy D. Blakely and Robert H. Edwards

For additional articles in this collection, see http://cshperspectives.cshlp.org/cgi/collection/

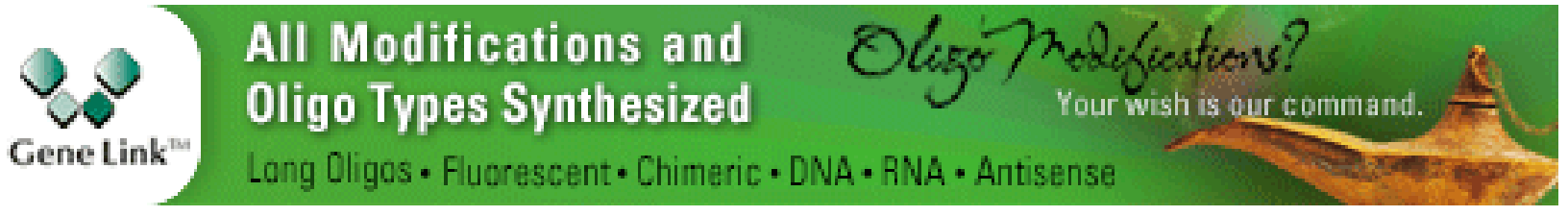

